\title{
EVIDENCE FOR LATE POLYNESIAN COLONIZATION OF NEW ZEALAND: UNIVERSITY OF WAIKATO RADIOCARBON MEASUREMENTS
}

\author{
T. F. G. HIGHAM and A. G. HOGG
}

Radiocarbon Dating Laboratory, School of Science and Technology, University of Waikato Private Bag 3105, Hamilton, New Zealand

\begin{abstract}
We present radiocarbon determinations for 271 New Zealand archaeological samples measured at the University of Waikato Radiocarbon Dating Laboratory between 1975 and 1995. A discard protocol is applied to the series and the list culled to winnow the acceptable dates from those that may incorporate error. None of the 221 acceptable ${ }^{14} \mathrm{C}$ determinations older than $600 \mathrm{BP}$ (in the case of terrestrial samples) or $930 \mathrm{BP}$ (in the case of marine and estuarine shell) extends beyond cal AD 1250. This conclusion supports the short chronology model of New Zealand prehistory presented by Anderson (1991).
\end{abstract}

\section{INTRODUCTION}

Radiocarbon dating the New Zealand prehistoric sequence has provided archaeologists and ${ }^{14} \mathrm{C}$ specialists alike with considerable challenge. The principal reason is the brevity of the prehistoric period. Until recently, it had been widely accepted that the first Polynesian colonizers made landfall on the last major landmass to be settled by humans ca. 1000 yr ago (Davidson 1984). Due to this brevity, ${ }^{14} \mathrm{C}$ dating at routine levels of precision $\left(\Delta^{14} \mathrm{C} \sigma= \pm 5-7 \%\right.$ ) has made it difficult to differentiate statistically between successive cultural strata with confidence (McFadgen 1982a). Recent developments in attainable precision have improved this situation, with precision of $\pm 2.5 \%$ in $\Delta^{14} \mathrm{C}$ now available in the University of Waikato Radiocarbon Laboratory. Despite this improvement, inherent wiggles in the calibration curve may spread converted ages, increasing uncertainty further.

There are two principal archaeological questions to which ${ }^{14} \mathrm{C}$ analyses have been applied in New Zealand, aside from the building of regional chronologies: the date of first colonization and the onset of paa (fort) building. Three general models have been proposed for the date of initial human colonization.

- Davidson $(1981 ; 1984)$ described the view of the majority of New Zealand archaeologists of the time when she outlined the orthodox model, with colonization beginning $c a$. AD 800 .

- Sutton (1987) presented a model influenced by Kirch's (1986) reanalysis of the prehistoric sequence of East Polynesia, suggesting that the dates for colonization of New Zealand may have to be revisited and could be much earlier than hitherto anticipated. The interpretation was based upon a number of natural sites containing dated charcoal lenses, possibly related to anthropogenic deforestation. Sutton stated that human colonization may have occurred between $\mathrm{AD} 0$ and 500 (Sutton 1987). Chester (1986), Sutton (1987) and Elliot et al. (1995) have utilized palynological and paleoenvironmental indicators such as this to argue for early human presence, represented by possible anthropogenic modification of a virgin land.

- Anderson (1991) took an alternative approach by examining ${ }^{14} \mathrm{C}$ determinations from sites already excavated. He analyzed ${ }^{14} \mathrm{C}$ determinations that predated $600 \mathrm{BP}$ (in the case of moa bone and charcoal) and $930 \mathrm{BP}$ (in the case of marine and estuarine shell) and pruned those that did not fit a set of acceptability criteria (Anderson 1991). Anderson's (1991) conclusion was that the acceptable ${ }^{14} \mathrm{C}$ determinations yielded evidence in support of a short prehistory, probably no more than 700-800 yr in duration, with colonization by $c a$. AD 1100 .

Similar research using the available corpus of ${ }^{14} \mathrm{C}$ data has suggested not only a late colonization date, but also a later date for the onset of paa building (Schmidt 1993, 1996; McFadgen, Knox and Cole 1994). Reanalysis of the critical Kaharoa Tephra has shown that its deposition in northern New 
Zealand occurred between cal AD 1300 and 1390 (Lowe et al., in press). No unequivocal cultural remains have been found beneath this layer of tephra. The earliest sustained periods of human deforestation occurred around, or soon after, the time of this eruption (Newnham et al., in press).

Recent accelerator mass spectrometry (AMS) dates on rat bone gelatin presented by Holdaway (1996) show bone from natural cave sites ranging in age from $\sim 400 \mathrm{BC}$ to $\sim 1200 \mathrm{AD}$. Because rats are a human commensal, such dates imply an earlier human presence than that indicated by the late settlement proponents. Anderson (1996), however, has dated rat bone gelatin samples from the Shag River Mouth site (Anderson, Smith and Higham 1996) that yield an age range at odds with one derived from more acceptable dating materials, suggesting the problem may be related to the material itself. Further investigations of the accuracy of rat bone for dating are currently underway (Beavan and Sparks, in press). Until more is known about the relative acceptability of this sample type, it would be wise to remain cautious about accepting these dates as reliable.

Anderson (1991) concentrated principally upon ${ }^{14} \mathrm{C}$ determinations from the Rafter Radiocarbon Laboratory at the Institute of Geological and Nuclear Sciences Ltd (IGNS) in Lower Hutt, New Zealand in his reanalysis of the ${ }^{14} \mathrm{C}$ record. In the Appendix to this paper, we present a list of ${ }^{14} \mathrm{C}$ determinations from New Zealand's other ${ }^{14} \mathrm{C}$ laboratory, at the University of Waikato in Hamilton, which began producing ${ }^{14} \mathrm{C}$ measurements in 1975 . Over $300{ }^{14} \mathrm{C}$ determinations have been made from New Zealand archaeological sites from 1975 to 1995 . The presentation of a date list is a useful exercise in its own right: many ${ }^{14} \mathrm{C}$ dates remain unpublished, still others are published in obscure reports and manuscripts. In addition, the publication of date lists enables the testing of previous models using updated data sets and encourages their use (cf. Spriggs 1996). Our intention in this paper, apart from presenting this list, is to consider how the results impact the differing colonization models for New Zealand. In order to do so, we first evaluate the measurements in terms of their accuracy for dating the New Zealand sequence by applying a discard protocol to them.

Trotter (1968), McFadgen (1982a), Law (1984), Anderson (1989), Anderson and McGovern-Wilson (1990), Caughley (1988), Anderson (1991) and McFadgen, Knox and Cole (1994) have cautioned against dating wood or wood charcoal derived from unknown, or long-lived tree species. All charcoal identifications are therefore included in the list. (McFadgen, Knox and Cole (1994) have provided a summary of New Zealand wood species and their estimated life span.) We have also included the identifications of marine and estuarine shell species that have been dated. Significant comments from submitters are given where applicable. Publications that contain the determinations listed, or discuss them in greater detail, are provided where possible. The ${ }^{14} \mathrm{C}$ determinations originate from a wide range of prehistoric sites and we present them by region, from north to south (Figs. $1,2)$. We also provide the New Zealand Archaeological Association's (NZAA) new site record number in parentheses after the site name where known (Smith 1994). Only ${ }^{14} \mathrm{C}$ analyses from submitters who have given their permission are included in this paper, except where the determinations have been published. In total, 41 determinations were withheld from this list at the request of submitters. (These were mostly samples dated recently and in preparation for publications.)

Sutton (1994: 247) has suggested that one of the shortcomings of the "short prehistory" model is the disproportionately large number of ${ }^{14} \mathrm{C}$ determinations that come from sites in the South Island and central North Island, to the exclusion of sites north of the Hauraki Gulf, and in Northland. This list is dominated by ${ }^{14} \mathrm{C}$ determinations that come from northern sites (Fig. 1) (70\% of the determinations are from North Island sites) and therefore should constitute an important test of Anderson's (1991) assumption that human arrival affected all areas at a similar time in prehistory (Sutton 1994). 


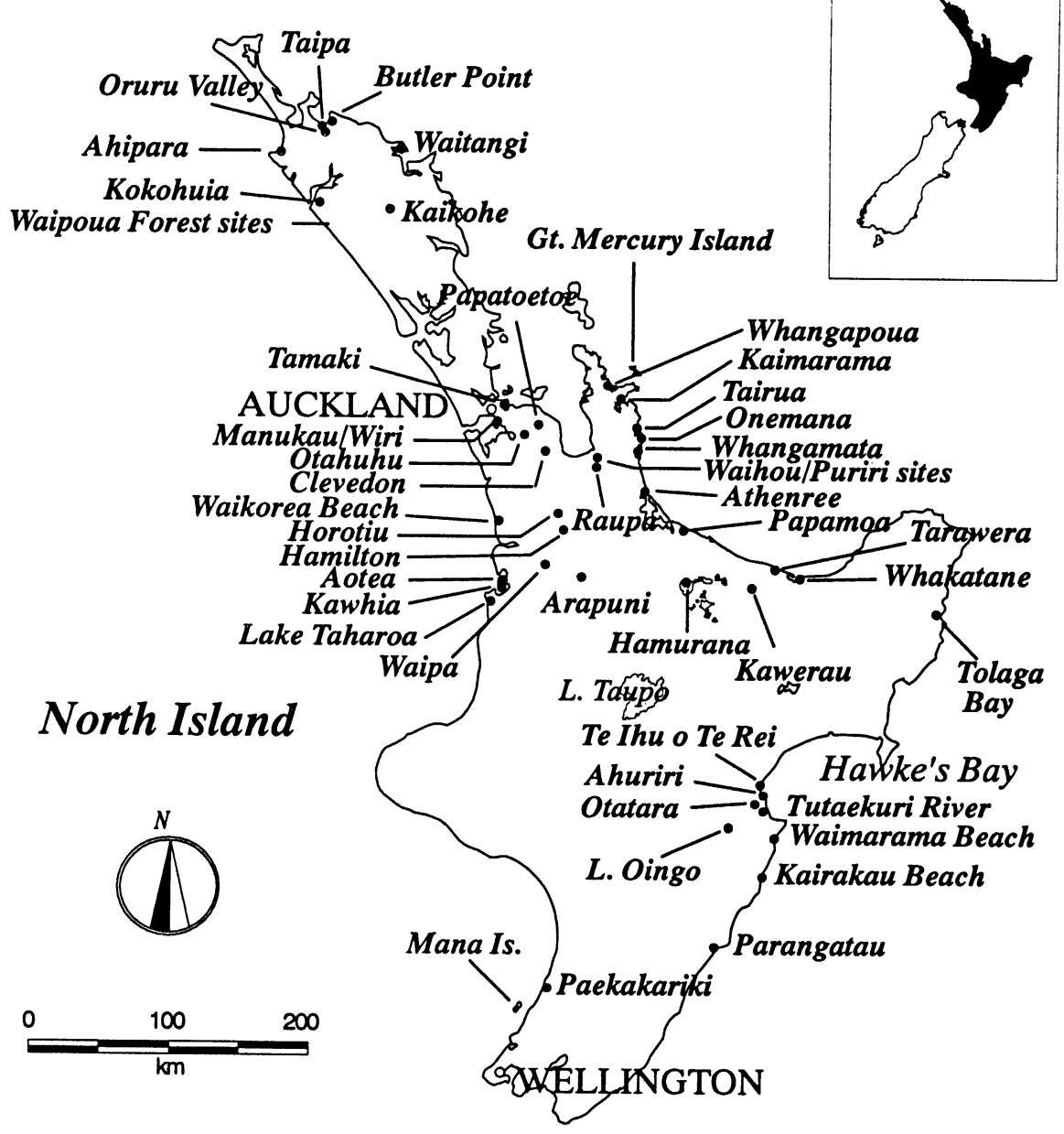

Fig. 1. North Island archaeological sites mentioned in the text and date list

\section{METHODS}

The Waikato Laboratory measures ${ }^{14} \mathrm{C}$ activity by the liquid scintillation counting (LSC) method (Hogg, Lowe and Hendy 1987). We measure $\beta$ decay activity in six LKB-Wallac Oy 1220 Quantulus ${ }^{\mathrm{TM}}$ spectrometers equipped with $0.35,3.0$ and $10.0 \mathrm{ml}$ synthetic silica vials in lead and aluminum holders (Hogg 1992). For New Zealand archaeological samples we use $3.0 \mathrm{ml}$ vials ( $2.7 \mathrm{~g}$ benzene), achieving a routine precision of $\pm 40-50{ }^{14} \mathrm{C} \mathrm{yr}\left(\Delta^{14} \mathrm{C} \sigma=5-6 \%\right.$ ). We use $10.0 \mathrm{ml}$ vials (7.5 g benzene) for our high-precision $\left(\Delta^{14} \mathrm{C} \sigma=2-3 \%\right){ }^{14} \mathrm{C}$ calibration program. All ages are reported as conventional ${ }^{14} \mathrm{C}$ ages $\mathrm{BP}$, based on the Libby half-life and calculated according to the recommendations outlined by Stuiver and Polach (1977). Conventional ${ }^{14} \mathrm{C}$ ages BP are reported with reference to the net corrected activity of the modern reference standard HOxII (SRM-4990C, NIST HOxII). We use ANU sucrose as a routine secondary laboratory standard (Polach 1976; Currie and Polach 1980). The standard error for each ${ }^{14} \mathrm{C}$ determination represents one standard deviation $(1 \sigma)$. A laboratory error multiplier $(K)$ of 1.22 has been included to increase standard errors measured since 1990 , after Stuiver and Pearson (1993). ${ }^{14} \mathrm{C}$ determinations are corrected for isotopic fractionation, normalized with respect to VPDB (Coplen 1994). 


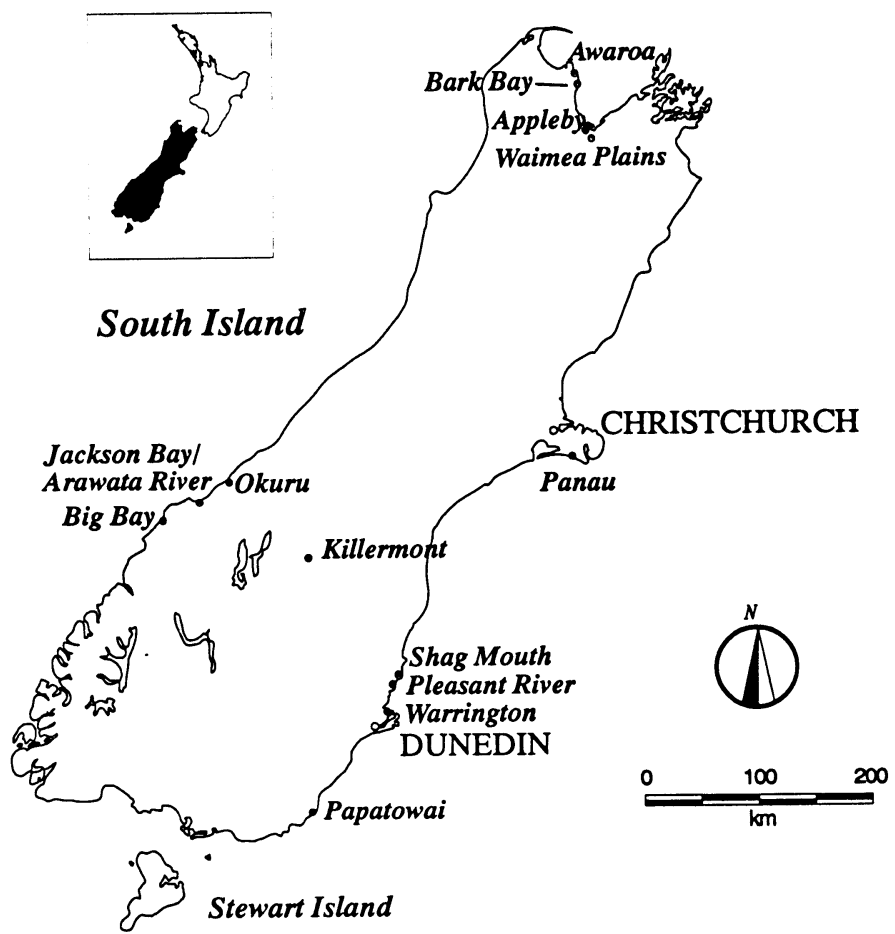

Fig. 2. South Island archaeological sites mentioned in the text and date list

\section{Rationale for Discard Protocols}

The application of a discard protocol is critical for examining the accuracy of multiple ${ }^{14} \mathrm{C}$ determinations from different archaeological sites. The brevity of the New Zealand prehistoric sequence requires a careful approach to sample selection and provenience, and a rigorous approach to the analysis of the corpus of available determinations. Spriggs $(1989,1996)$, Anderson (1991), Spriggs and Anderson (1993) and Schmidt $(1993,1996)$ have presented protocols for the discard of New Zealand and Polynesian archaeological ${ }^{14} \mathrm{C}$ determinations on the basis of sample reliability and archaeological integrity. Similarly, Kuzmin and Tankersley (1996) have ranked ${ }^{14} \mathrm{C}$ dates in terms of sample type and stratigraphic integrity in their analysis of the date of colonization of Siberia. We have developed a discard protocol for accepting or rejecting assays listed in the Appendix to examine their accuracy in dating archaeological events, and to consider how the earliest acceptable determinations challenge the various colonization hypotheses.

\section{Archaeological Sample Protocols}

The archaeological discard protocol is as follows:

1. Charcoal samples from species that are unidentified and may possess a high inbuilt age (McFadgen 1982a) and therefore do not date the archaeological event accurately, are rejected.

Wk-94 from Great Mercury Island and the series of dates from Hamurana, Rotorua (Wk-1218 to 1222 , inclusive) are rejected as unidentified. The Aotea and Kawhia dates Wk-31 and -32 are unidentified and rejected. Wk-1899 was identified, but its exact sample constituents are unknown so it is rejected. The same applies to Wk-1389 and 1390 from Jackson Bay. Wk-1088 is of unidentified charcoal although it is listed as dominated by twigs; nevertheless, as Anderson (1991: 780) has 
shown, twigs and branchwood that originate from long-lived species may still incorporate inbuilt age. This date is therefore rejected. Wk-2737 from Arapuni is composed of unidentified charcoal.

2. Charcoal samples that are identified but belong to species of trees that may possess a high inbuilt age and therefore do not date the archaeological event accurately, are rejected.

Wk-1907, -1910 and -1912 from Raoul Island are all rejected because they are dominated by Metrosideros kermadecensis, a long-lived tree. Wk-968 from Whangapoua comes from maire branchwood (Nestigis sp.). According to McFadgen, Knox and Cole (1994), although this is classified as a medium-span species (100-300 yr), it can survive for much longer. The Hamilton samples Wk$2703,-2704$ and -2736 are dominated by long-lived species and are rejected.

3. Dates obtained from materials that have been shown to produce erroneous ${ }^{14} \mathrm{C}$ ages, such as riverine shells, are rejected.

All dates of Amphibola crenata (mudsnail) from the list are rejected. These have been shown to yield erroneous ${ }^{14} \mathrm{C}$ dates (Law 1984; Anderson 1989, 1991; Higham 1993; Higham and Hogg 1995; Hogg, Higham and Dahm, in press). Wk-2367, -2633 and -2507 are of Amphibola crenata.

Wk-2738 from Arapuni is composed of freshwater Hyridella menziesii shell from a Waipa River bank site. That the shell overlies alluvial deposits dated at $c a .1850$ BP or younger indicates that the date returned is stratigraphically inverted and clearly too old. Freshwater shells such as these may incorporate an unknown reservoir age. It is also possible that the sample may originate from natural shell material redeposited at the site to form a living floor or terrace.

4. Single dates from dispersed charcoal or sediments excavated from agricultural soils, are rejected. These dates may possess error due to inbuilt age (McFadgen 1982a) or fail to relate sample to event.

Wk-1754 is rejected. This sample of sediment comes from a drainage ditch and provides a minimum age for the feature. It may have incorporated carbon of unknown inbuilt age. Wk-2702 is dominated by a selection of short-lived species, but two water-rolled "pebbles" of totara are indicative of inherent provenience problems, according to Dr. R. Wallace, who identified the samples. The sample originates from a borrow pit feature, the remnant of pits excavated in prehistory for extracting coarse grit and pebbles used to modify soils (McFadgen 1980). The accuracy of dates on samples from features such as this is questionable. The charcoal may derive from earlier burnoff of vegetation and ground cover. Wk-2705 and -2706 are similarly unreliable and rejected.

5. Dates that are 300 yr or greater adrift in a series from an identical stratigraphic horizon that is otherwise statistically indistinguishable at $1 \sigma$, are rejected. In these instances, especially in the case of charcoal, there is the possibility that inbuilt age may have made the determination artificially old.

6. Samples that may have been contaminated post-depositionally or inadequately pretreated, are rejected.

7. Samples from areas with equivocal cultural context or in which redeposition may have occurred, are rejected.

Wk-1754 falls into this category as well as into category 4. Wk-1911 from Raoul Island dates a paleosol, whereas Wk-1907 is from a "disturbed context". Wk-1143 also dates deforestation, which may not be human-related. Layers 3 and 4 of the Pleasant River Area D series have been mixed in places, and material from a later occupation dated at $c a .400 \mathrm{BP}$ has become incorporated with material from an earlier ca. $600 \mathrm{BP}$ occupation. All of the results from Area D, except for those determi- 
nations of layer 4 moa eggshell, whose context was secure, are therefore rejected for this analysis (Allingham, personal communication).

8. Marine and estuarine shell dates that originate from areas where there may be a high risk of oceanic upwelling or old carbon dissolution, are rejected.

9. Dates that are based upon mixtures of different sample types, such as charcoal and bone or mixtures of shell of different species, are rejected. (N.B.: No bone samples from New Zealand archaeological sites were dated at the Waikato Laboratory between 1975 and 1995.)

Wk-1151, $-1168,-2306,-2307$ fall into this category and are rejected.

10. Determinations of shell of unknown species are rejected. In this category, there is the possibility that shell of unreliable species such as Amphibola crenata may have become incorporated in the sample.

Wk-2273, $-2274,-2872,-2873,-2874,-2875$ and -3048 were unidentified shell and are rejected.

\section{Radiocarbon Protocols}

The preceding protocols were devised from an archaeological perspective; thus, they take no account of the analytical and statistical variables involved in $\mathrm{a}^{14} \mathrm{C}$ determination. Clearly, a protocol for the rejection or acceptance of a ${ }^{14} \mathrm{C}$ date must embrace these parameters in addition to archaeological variables, since the utility of any ${ }^{14} \mathrm{C}$ measurement is dependent upon its archaeological context, sample composition and the rigor of the laboratory analysis and measurement. Understandably, the task of combining these variables into a single discard protocol is complex, particularly as the release of a ${ }^{14} \mathrm{C}$ determination by a laboratory implies the acceptability of that ${ }^{14} \mathrm{C}$ measurement. We suggest that additional discard variables, related to Quality Assurance programs, be associated with "chronometric hygiene" analyses such as this, particularly when multiple laboratory date lists are being examined. We offer three possibilities here by way of example.

1. A laboratory error multiplier $(K)$ must be incorporated into the standard error for any ${ }^{14} \mathrm{C}$ date to account for variation in reproducibility in routine sample dating (Stuiver and Pearson 1993).

2. The laboratory must demonstrate its accuracy by reference to the library of international standards prepared by the International Atomic Energy Agency (LAEA) Intercomparison and the Third International Radiocarbon Intercalibration (TIRI) (Gulliksen and Scott 1995).

The exceptions are in instances where the submitted values for a particular standard are so spread that the consensus value loses meaning as a reflection of the "true" age of the sample (cf. IAEA C4 standard, Rozanski et al. 1992; Hogg et al. 1995).

3. All ${ }^{14} \mathrm{C}$ dates must be ${ }^{14} \mathrm{C}$ ages BP based upon the recommendations of Stuiver and Polach (1977) with correction for isotopic fractionation.

\section{RESULTS}

In the culled list are $221{ }^{14} \mathrm{C}$ results from New Zealand sites that we suggest are acceptable. We rejected 50 determinations in total; 25 of charcoal, 21 of marine, estuarine or freshwater shell and 4 wood, sediment or eggshell samples. Of the acceptable determinations, 159 are of marine or estuarine shell, 50 are charcoal and 12 are of other sample types, principally wood and moa eggshell. 
We have collated those ${ }^{14} \mathrm{C}$ determinations of charcoal, wood and moa eggshell that extend beyond $600 \mathrm{BP}$, and marine and estuarine shell dates that extend beyond $930 \mathrm{BP}$ (after Anderson (1991)) to examine the earliest possible colonization dates they imply. The resultant dates come from cultural deposits in sites in both islands that are considered early or Archaic phase occupations. We calibrated the shell dates using the marine curve of Stuiver and Braziunas (1993) with a local reservoir depletion, or $\Delta \mathrm{R}$, calculated at $-25 \pm 15{ }^{14} \mathrm{C}$ yr (Higham and Hogg 1995). We calibrated the charcoal and eggshell dates using the curves of Stuiver and Becker (1993), with a $-27{ }^{14} \mathrm{C}$ year offset subtracted after McCormac et al. (in preparation) for Southern Hemispheric terrestrial samples.

The 22 shell determinations possess no calibrated age ranges that extend beyond AD 1250 (Fig. 3). None of the 9 pre-600 BP calibrated charcoal series range beyond AD 1250 either (Fig. 4). Among the eggshell determinations, there are also no determinations that approach the mid-13th century $A D$ (Fig. 5).

All three sample types, then, show very close agreement in estimating the earliest calibrated age, which in no case challenges the 12 th century. The earliest calibrated range across all sample types is very similar. This agreement is due principally to the application of the discard protocol and the rejection of measurements that are likely to be aberrant.

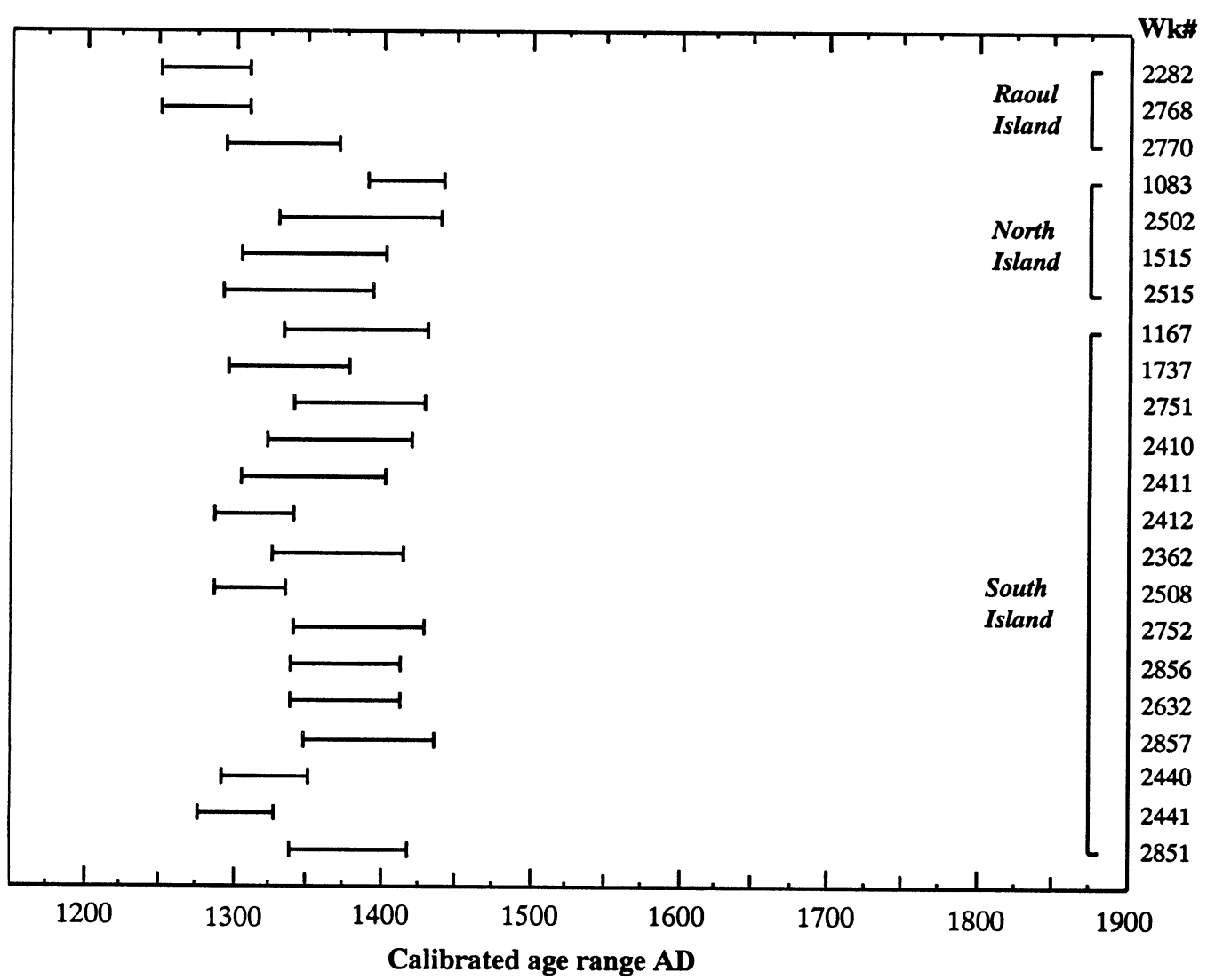

Fig. 3. Calibrated ${ }^{14} \mathrm{C}$ dates of shell from New Zealand archaeological sites that predate $930 \mathrm{BP}$. Determinations were calibrated after Stuiver and Braziunas (1993) with a $\Delta \mathrm{R}$ of $-25 \pm 15^{14} \mathrm{C}$ yr (Higham and Hogg 1995) using CALIB 3.0.3c (Stuiver and Reimer 1993). 


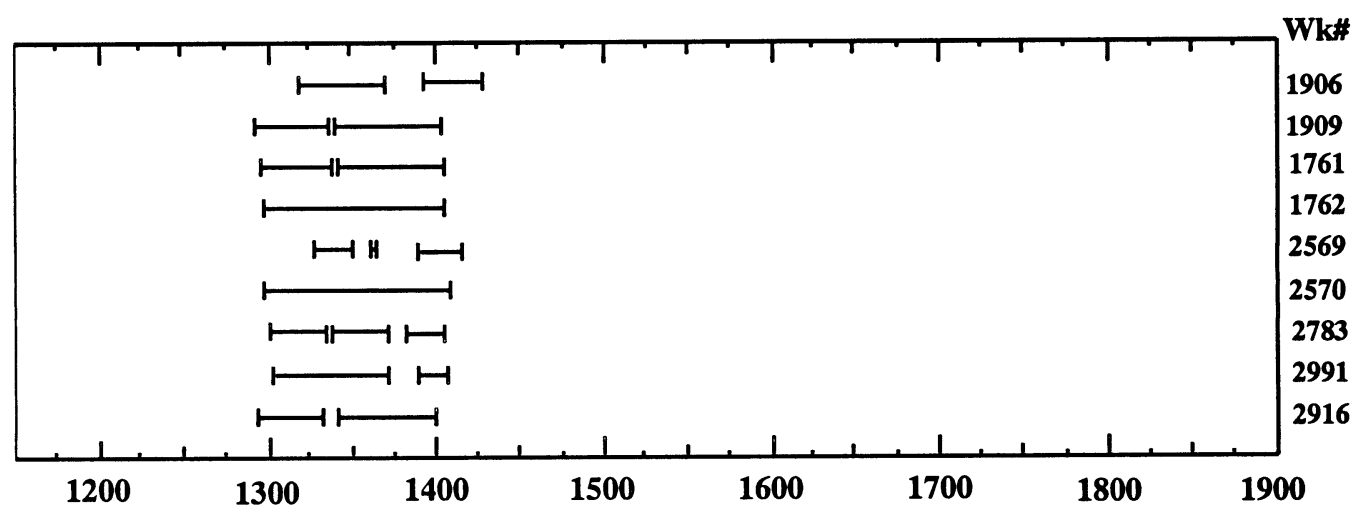

Calibrated age range $\mathrm{AD}$

Fig. 4. Calibrated ${ }^{14} \mathrm{C}$ dates of charcoal from New Zealand archaeological sites that predate $600 \mathrm{BP}$. Determinations were calibrated using Stuiver and Becker (1993) with a $-27{ }^{14} \mathrm{C}$ yr offset applied (McCormac et al., in preparation). Wk-1906 and -1909 are dates from Raoul Island, the Kermadecs. The remainder are from sites in the South Island.

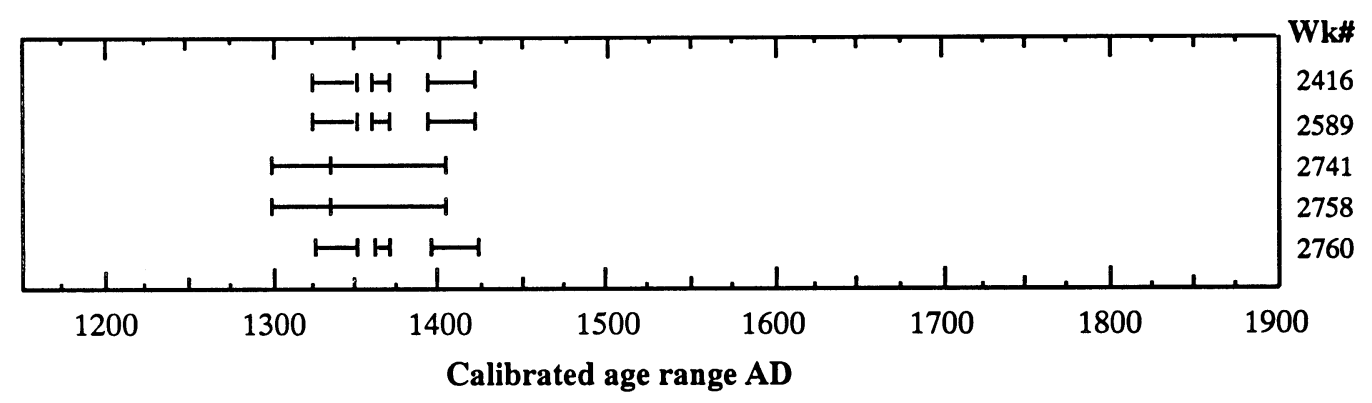

Fig. 5. Calibrated ${ }^{14} \mathrm{C}$ dates of moa eggshell from New Zealand archaeological sites that predate $600 \mathrm{BP}$. Determinations were calibrated as in Fig 4. All of the determinations are from sites in the South Island.

A feature of the calibrated data shown in Figures 3, 4 and 5 is the small number of acceptable North Island determinations that exceed the threshold for this analysis of colonization dates. In Anderson's (1991) analysis, $\sim 35 \%$ of the available early ${ }^{14} \mathrm{C}$ determinations came from North Island sites, compared to $\sim 65 \%$ from the South Island. In the Waikato list, only four North Island determinations of the shell series exceed $930 \mathrm{BP}$, and none of the charcoal and eggshell samples extend beyond $600 \mathrm{BP}$. Obviously, sampling considerations mean it would be unwise to overinterpret these data. In the shell series, for instance, the South Island series is dominated by determinations from the Shag River Mouth site. Nevertheless, the general tendency in both ${ }^{14} \mathrm{C}$ lists is for southern sites to yield a larger number of acceptable determinations beyond cal $600 \mathrm{BP}$. This may suggest that in the earliest phases of prehistory the South Island was the focus of population and settlement, although both were colonized at a similar time in prehistory.

\section{ConClusion}

Anderson (1991: 792) concluded that there are no sites in New Zealand dated to before the 12th century $\mathrm{AD}$ and that positing colonization about that time appeared to be "robust in the face of potential objections". In the Waikato series, no calibrated age ranges extend beyond $c a$. AD 1250 . Our data 
therefore support the late settlement model, with human occupation beginning ca. $700 \mathrm{cal}$ BP ( $c f$. McFadgen, Knox and Cole 1994).

\section{ACKNOWLEDGMENTS}

We thank Professor K. M. Mackay, Dean of the School of Science and Technology, University of Waikato, for his invaluable support to the laboratory. Mrs. H. McKinnon, Mrs. M. Farrant, Mrs. M. Rabjohns, Mr. M. Schmidt and Miss F. Petchey have provided laboratory assistance. We thank Dr. C. Hendy, Mrs. W. Jackson (Chemistry Department, University of Waikato) and Mr. S. Cooke (Earth Sciences Department, University of Waikato) for mass spectrometry measurements. We also thank all submitters for their support and cooperation. We are very grateful to the late $\mathrm{Dr}$. H. A Polach, Radiocarbon Laboratory, Research School of Pacific Studies, Australian National University, Canberra, Australia, for his input to the laboratory. Mr. T. Walton, Dr. B. McFadgen (Department of Conservation, Wellington) and Mr. O. Wilkes (Department of Conservation, Hamilton) provided some of the new NZAA site numbers. Finally, we extend a debt of gratitude to Dr. R. Wallace of Auckland University's Anthropology Department, on behalf of the archaeological community, for his important wood charcoal identification work.

\section{ARChaEOlogical dates}

\section{RAOUL ISLANDI}

Raoul Island series

(Submitted 1 October 1990, by L. Johnson, Department of Conservation, Auckland)

\section{Woolshed Flat, Farm Terraces (K036/2)}

Wk-1906. R.I.1

Charcoal

$600 \pm 60$

$\delta^{13} C=-25.7 \%$

Comment: (L.J.) The date will provide a minimum possible age for prehistoric occupation.

N.B.: charcoal species identified as pohutukawa (Metrosideros kermadecensis), mahoe (Melicytus ramiflorus), kawakawa (Macropiper excelsum), karo (Pittosporum crassifolium), Coprosma sp., hutu (Corarra lucida var. lanceolata).

Wk-1907. R.I.2

Modern

Charcoal

$$
\delta^{13} \mathrm{C}=-24.9 \%
$$

Comment: (L.J.) To provide a date for prehistoric settlement on the terraces.

N.B.: charcoal identified as pohutukawa (Metrosideros kermadecensis). Obtained from a "disturbed context".

Wk-1908. R.I.3

Charcoal

$$
\delta^{13} C=\begin{array}{r}
\mathbf{5 8 0} \pm \mathbf{5 0} \\
-25.1 \% \circ
\end{array}
$$

Comment: (L.J.) The date should provide a minimum possible age for construction of the archaeological feature.

\footnotetext{
${ }^{1}$ Raoul Island, the largest of the Kermadec group, is ca. $1000 \mathrm{~km}$ from New Zealand $\left(29-31.5^{\circ} \mathrm{S}, 178-179^{\circ} \mathrm{W}\right)$. The prehistory of the Kermadecs is closely linked to New Zealand, however, through the discovery of obsidian from Mayor Island (Bay of Plenty) in cultural deposits on Raoul (Anderson and McFadgen 1990). This suggests that having found New Zealand, Polynesians succeeded in returning at least halfway back to island Polynesia.
} 
N.B.: charcoal species identified as pohutukawa (Metrosideros kermadecensis), kawakawa (Macropiper excelsum), karo (Pittosporum crassifolium), mahoe (Melicytus ramiflorus and Myrsine kermadecensis).

\section{Coral Bay (K036/4)}

Wk-1909. R.I.4

$660 \pm 50$

Charcoal

$\delta^{13} C=-25.4 \%$

Comment: (L.J.) The age of the settlement at Coral Bay.

N.B.: charcoal identified as mahoe (Melicytus ramiflorus and Myrsine kermadecensis) and pohutukawa (Metrosideros kermadecensis).

\section{Low Flat (K036/1)}

Wk-1910. R.I.5

Charcoal

$800 \pm 40$

$\delta^{13} C=-25.5 \%$

Comment: (L.J.) Will provide a date for the occupation of the upper cultural layer at Low Flat.

N.B.: charcoal is pohutukawa (Metrosideros kermadecensis), all other species unidentified.

Wk-1911. R.I.6

Modern

Wood

$$
\delta^{13} \mathrm{C}=-24.5 \%
$$

Comment: (L.J.) This ${ }^{14} \mathrm{C}$ date should mark the terminal point in the development of the paleosol. N.B.: wood sample composed of candlenut (Aleurites mollucana).

Wk-1912. R.I.7

Charcoal

Comment: (L.J.) Age of occupation of the lower cultural horizon.

N.B.: charcoal is $93 \%$ pohutukawa (Metrosideros kermadecensis), $7 \%$ karo (Pittosporum crassifolium). Sample comes from a lower cultural horizon earth oven in association with obsidian blades, adze roughouts and midden remains.

Wk-2282. U.C.H.2 R.A.O

$1100 \pm 45$

Shell (Patella kermadecensis)

$$
\delta^{13} \mathrm{C}=+0.8 \%
$$

Comment: (L.J.): Sample should provide a minimum age for the occupation of the upper cultural horizon.

N.B.: see Johnson (1991, 1995).

\section{Low Flat (K036/1)}

(Submitted 1 December 1992 by T. Higham, Radiocarbon Dating Laboratory, University of Waikato, Hamilton).

Wk-2768. Low Flat upper layer

Shell (Patella kermadecensis)

$1100 \pm 45$

Wk-2769. Low Flat upper layer

Shell (Patella kermadecensis)

$\delta^{13} \mathrm{C}=+1.3 \%$

Wk-2770. Low Flat lower layer

$1050 \pm 45$

Shell (Patella kermadecensis)

$1040 \pm 45$

$\delta^{13} \mathrm{C}=+1.3 \%$ 
N.B.: see Johnson (1995), Higham and Johnson (in press).

\section{NORTHLAND}

\section{Mangonui (004/116)}

(Submitted 27 January 1989 by L. Johnson, Department of Conservation, Auckland)

Wk-1373. C.L.10 Level 5

$610 \pm 50$

Shell (Austrovenus stutchburyi)

$\delta^{13} \mathrm{C}=-2.1 \%$

Comment: (L.J.) The sample should date the latest phase of occupation of the site and offer the upper parameter for occupation of the site as a whole.

Wk-1374. C.L.2 Level 9

$570 \pm 50$

Shell (Austrovenus stutchburyi)

$\delta^{13} C=-2.0 \%$

Comment: (L.J.) as above. N.B.: see Johnson (1992).

\section{Butler Point, Mangonui series (004/56)}

(Submitted 15 May 1992 by A. Slocombe/J. Maingay, Department of Conservation, Whangarei)

Wk-2384. 004/56 147 Area B base of pebble layer

Charcoal

Modern

$\delta^{13} C=-28.4 \%$

Comment: (A.S.) Date of occupancy of paa is not known. Dating of different material excavated there could indicate when this took place and whether successive occupations of the site occurred.

N.B.: sample of charcoal identified as seven fragments of Kunzea/Leptospermum and three of broadleaf twigs (Griselinia littoralis).

Wk-2500. 004/56 54

$540 \pm 60$

Shell (Austrovenus stutchburyi)

$$
\delta^{13} \mathrm{C}=+1.6 \%
$$

Comment: (A.S.) as for Wk-2384. Sample comes from Area $\mathrm{F}$ under defensive bank layer 3 posthole.

Wk-2563. 004/56 65

Shell (Austrovenus stutchburyi)

$720 \pm 60$

$\delta^{13} C=+1.6 \%$

Comment: (J.M.) The shell appears to have been deposited prior to construction of the major earthworks of the paa. It could provide a date for an earlier undefended occupation level. Sample is composed of shell fill in a posthole in layer 3.

Wk-2922. 004/56 33 (layer 2)

Shell (Austrovenus stutchburyi)

$500 \pm 50$

Comment: (A.S.) This sample could date a period of occupation of the paa site.

Wk-2923. 004/56 66 (layer 4)

Shell (Austrovenus stutchburyi)

$\mathbf{7 0 0} \pm \mathbf{5 0}$

$\delta^{13} \mathrm{C}=+1.0 \%$

Comment: (A.S.) This sample could date a period of occupation of the paa site.

Wk-2924. 004/56 (A) L6 (layer 2)

Shell (Austrovenus stutchburyi) 
Comment: (A.S.) This sample could date a period of occupation of this coastal camp site.

N.B.: Wk-2922, -2923 and -2924 submitted 10 May 1993 by A. Slocombe, Department of Conservation, Whangarei.

Wk-3318. 004/56 4 Area D trench 3, top of layer 2 $670 \pm 60$

Shell (Austrovenus stutchburyi)

$$
\delta^{13} \mathrm{C}=+1.0 \%
$$

Comment: (S.B.) Probably will reflect the final occupation of the paa as a traditional fortification.

Wk-3933. O04/56/1995/1 Area D, fill of feature under layer 3

$640 \pm 50$

Shell (Austrovenus stutchburyi)

$\delta^{13} \mathrm{C}=+1.1 \%$

Comment: (S.B.) Dates the dismantling of a large structure (house or platform).

Wk-3934. O04/56/1995/2 Area $F$, fill of feature in layer 3

Shell (Austrovenus stutchburyi)

$\mathbf{5 3 0} \pm \mathbf{5 0}$

$\delta^{13} \mathrm{C}=+0.8 \%$

Comment: (S.B.) Dates the dismantling of a large structure (house or platform) inside fortification.

Wk-3935. O04/56/1995/3 Area F, fill of feature in top of layer 4

$\mathbf{5 7 0} \pm \mathbf{5 0}$

Shell (Austrovenus stutchburyi)

$\delta^{13} \mathrm{C}=+1.2 \%$

Comment: (S.B.) Dates the end of the occupation of a structure inside the defenses of a site.

Wk-3936. 004/56/1995/4 Area D, terrace A, layer 2

Shell (Austrovenus stutchburyi)

$580 \pm 50$

$\delta^{13} \mathrm{C}=+0.8 \%$

Comment: (S.B.) Dates the construction of a shell-paved terrace outside defended area of site.

N.B.: Wk-3933 to -3935 submitted 28 June 1994 by S. Bulmer, Department of Conservation, Auckland. Wk-3318 submitted 28 June 1994 by S. Bulmer, Department of Conservation, Auckland. Wk2384 submitted 2 March 1992 by A. Slocombe, Department of Conservation, Whangarei. (See Bulmer and Maingay, in preparation.)

Taipa, Doubtless Bay (O04/580)

(Submitted 18 May 1990 by L. Johnson, Department of Conservation, Auckland)

Wk-1753. M.S.4(6)

$700 \pm 45$

Shell (Paphies australis)

$\delta^{13} C=+1.6 \%$

Comment: (L.J.) The relationship between the midden from which this sample was taken and the wetland drainage system that we wish to date is that the two should be contemporary. However, I cannot be certain about this. Apart from the drainage system itself, the midden that occurred in the swamp was the only other feature that provided dateable material.

Wk-1754. D.S.1

$840 \pm 55$

Sediment

$\delta^{13} C=-27.6 \%$

Comment: (L.J.) This sample should provide a minimum possible age for construction of the wetland drainage system. It appeared from the excavated profile that the fill from which the sample was taken was deposited toward the end of the use of the system or shortly after the point at which the system became redundant. 


\section{Oruru Valley (004/253 and 004/260)}

(Submitted by Y. Marshall, Anthropology Department, University of Auckland)

Wk-976. 004/253

$830 \pm 50$

Shell (Paphies australis)

$\delta^{13} \mathrm{C}=+2.2 \%$

Comment: (Y.M.) To date undefended storage complex in the Oruru Valley.

Wk-977. O04/260 T.P.I

Shell (Paphies australis)

$770 \pm 50$

$\delta^{13} \mathrm{C}=+2.1 \%$

Comment: (Y.M.) as above.

Wk-978. O04/260b

Shell (Paphies australis)

$660 \pm 50$
$\delta^{13} C=+2.2 \% 0$

Comment: (Y.M.) To date storage complex in the Oruru Valley.

\section{Reef Point, Ahipara (N05/301)}

(Submitted 7 June 1991 by L. Johnson, Department of Conservation, Auckland)

Wk-2100. N05/301.1.

Wood

$400 \pm 50$

$\delta^{13} C=-26.1 \%$

N.B.: twigs identified as pohutukawa (Metrosideros excelsa), Cassinia retorta, ngaio (Myoporum laetum), mapou (Myrsine australis), matai (Prumnopitys taxifolia). All shrubs selected.

Ahipara 2 (N05/302)

(Submitted 15 April 1992 by A. Slocombe, Department of Conservation, Whangarei)

Wk-2501. Sample 1 (layer 2)

Shell (Turbo smaragda)

$$
\begin{array}{r}
630 \pm 60 \\
\delta^{13} C=+3.0 \%
\end{array}
$$

Comment: (A.S.) This could date a more recent period of occupation at this coastal camp site.

Wk-2502. Sample F36B (layer 4)

Shell (Turbo smaragda)

$950 \pm 60$

$\delta^{13} \mathrm{C}=+3.0 \%$

Comment: (A.S.) This sample could date one of the earliest periods of occupation at this coastal camp site.

\section{Waitangi (P05/611)}

(Submitted 9 December 1992 by A. Slocombe, Department of Conservation, Whangarei)

Wk-2773. Sample 1 (layer 4)

Shell (Austrovenus stutchburyi)

$$
\begin{array}{r}
620 \pm 50 \\
\delta^{13} C=+0.7 \% 0
\end{array}
$$

Comment: (A.S.) This sample could provide a date for an early period of settlement at this site.

\section{Kokohuia (006/317)}

(Submitted 7 August 1987 by M. Taylor, Department of Conservation, Waipoua Forest, Dargaville) 
Wk-1086. Koko-10

Shell (Paphies australis)

$880 \pm 50$

$\delta^{13} \mathrm{C}=+1.6 \%$

Comment: (M.T.) Date of base of midden excavated at Kokohuia, Omapere.

\section{Kokohuia (006/317)}

(Submitted 9 June 1992 by J. Maingay, Department of Conservation, Whangarei)

Wk-2564. 006/317 40 (layer 2)

Shell (Austrovenus stutchburyi)

$790 \pm 60$

$\delta^{13} C=+1.6 \%$

Comment: (J.M.) A previous sample, Wk-1086, taken by M. Taylor from a slope northwest of excavation dated to $880 \pm 50 \mathrm{BP}$. This sample is to determine whether the areas of the site are contemporaneous.

\section{Kaikohe (P06/82)}

(Submitted 4 June 1995 by A. Slocombe, Department of Conservation, Whangarei)

Wk-3919. P06/82/1

Wood

$220 \pm 50$

$\delta^{13} C=-24.8 \%$

Comment: (A.S.) This sample will date a period of occupation of the area possibly associated with paa sites located nearby and may also determine whether or not PO6/82/1 and PO6/82/2 are contemporaneous.

$N . B .:$ the wood was identified as hinau kernels (Elaeocarpus dentatus).

Wk-3920. P06/82/2

Wood

$220 \pm 40$

$\delta^{13} C=-24.8 \%$

Comment: (A.S.) By association, this sample could date the deposition of the artifacts and may also determine whether or not $\mathrm{PO} / 82 / 1$ and $\mathrm{PO} / 82 / 2$ are contemporaneous.

N.B.: the wood was identified as hinau kernels (Elaeocarpus dentatus). See Slocombe (1996).

Waipoua Forest series

(Submitted 7 August 1987 by M. Taylor, Department of Conservation, Waipoua Forest, Dargaville)

Wk-1083. 006/290 1

Shell (Turbo smaragda)

Comment: (M.T.) Dates of deposition of midden at Motuhuru, archaeological site O06/290. Predates forest clearance.

Wk-1084. 006/171 67

Charcoal

Comment: (M.T.) Date of occupation of pit site 006/171.

N.B.: charcoal species identified as Myrsine sp., rangiora (Brachyglottis repanda), akeake (Dodonaea viscosa), makamaka (Ackama rosifolia), Coprosma sp., Olearia sp.

Wk-1085. O06/249 132

Charcoal

$460 \pm 50$

$\delta^{13} C=-26.4 \%$ 
Comment: (M.T.) Date of occupation of house site O06/249, Waipoua Forest.

N.B.: charcoal consisted of the following: twig species-rewarewa (Knightia excelsa), hinau (Elaeocarpus dentatus), matai (Prumnopitys taxifolia), puriri (Vitex lucens), kohekohe (Dysoxylum spectabile), tarairi (Beilschmeidia tarairi), akeake (Dodonaea viscosa), mahoe (Melicytus ramiflorus); short-lived species-rangiora (Brachyglottis repanda), pate (Scheffliera digitata), fivefinger (Pseudopanax arboreus), makamaka (Ackama rosifolia), Pittosporum sp., Coprosma sp., Olearia sp.

Wk-1087. O06/170

Charcoal

$360 \pm 50$

$\delta^{13} C=-22.3 \%$

Comment: (M.T.) Date of occupation of pit site O06/170, Waipoua Forest.

N.B.: charcoal consisted of mainly short-lived species; makamaka (Ackama rosifolia), rata vine (Metrosideros robusta), rangiora (Brachyglottis repanda), putaputaweta (Carpodetus serratus), also some ponga (Cyathea dealbata).

Wk-1088. 006/170-12

Charcoal

$480 \pm 45$

$\delta^{13} C=-25.8 \%$

Comment: (M.T.) Date of occupation of pit site O06/170.

$N . B$. : charcoal was unidentified shrub species, all twig wood.

AUCKLAND

Theatre Lane, Auckland City (R11/1559)

(Submitted by S. Best, Department of Anthropology, Auckland University)

Wk-1142. R11/1559-C14/1

Shell (Austrovenus stutchburyi)

$850 \pm 50$

$\delta^{13} \mathrm{C}=+1.6 \%$

Comment: (S.B.) The first date associated with Maori occupation in central Auckland and its relationship to forest clearance in the area.

Wk-1143. R11/1559-C14/2

Wood

$\mathbf{7 5 0} \pm \mathbf{5 0}$

$\delta^{13} C=-25.3 \%$

Comment: (S.B.) Dates of deforestation in the Waihorotiu Stream watershed, and whether this occurred within the period of human occupation.

N.B.: wood was described as "leaf litter". See Best (1992).

Newmarket site (R11/1694)

(Submitted 24 April 1991 by D. Wilson, Department of Anthropology, University of Auckland)

Wk-2051.

Modern

Charcoal

$\delta^{13} C=-24.8 \%$ 。

Comment: (D.W.) A ${ }^{14} \mathrm{C}$ date (charcoal) excavated at site R11/1694 Auckland from prehistoric earth oven.

N.B.: charcoal identified as Coprosma sp. and twigs—kohekohe (Dysoxylum spectabile). 


\section{Cryers Road, Tamaki (R11/1519)}

(Submitted 20 October 1987 by C. Fredericksen and E. Visser, New Zealand Historic Places Trust, Private Bag, Auckland)

Wk-1126. LN1

$$
\begin{array}{r}
300 \pm 50 \\
\delta^{13} C=-24.8 \%
\end{array}
$$

Charcoal

Comment: (C.F./E.V.) Dates important in establishing the phases of activity on the terrace site, able to correlate it with ${ }^{14} \mathrm{C}$ dates from terrace and R11/1519; activities associated with occupants of Green Mount, East Tamaki.

N.B.: charcoal identified as Hebe sp., fern, ngaio (Myoporum laetum), kapuka (broadleaf) (Griselinia littoralis), tawa (Beilschmeidia tawa), lancewood (horoeka) (Pseudopanax crassifolius), Nestigis sp., matai (Prumnopitys taxifolia).

Wk-1127. LN3

Shell (Austrovenus stutchburyi)

$750 \pm 45$

$\delta^{13} \mathrm{C}=+1.4 \%$

Comment: (C.F./E.V.) Dates are important in establishing the length of prehistoric Maori activity in East Tamaki and the Auckland region generally.

Wk-1128. LN4

Shell (Austrovenus stutchburyi)

$700 \pm 45$

$\delta^{13} \mathrm{C}=+0.7 \%$

Comment: (C.F./E.V.) as above.

Wk-1129. LN5

Shell (Austrovenus stutchburyi)

$\mathbf{6 7 0} \pm \mathbf{4 0}$

$\delta^{13} \mathrm{C}=+0.7 \%$

Comment: (C.F./E.V.) as above.

Wk-1130. LN6

Shell (Austrovenus stutchburyi)

$590 \pm 40$

Comment: (C.F./E.V.) as above.

$\delta^{13} \mathrm{C}=+1.0 \%$

Wk-1131. LN7

Shell (Austrovenus stutchburyi)

$510 \pm 40$

$\delta^{13} \mathrm{C}=+1.0 \%$

Comment: (C.F./E.V.) as above.

Wk-1132. LN8

Shell (Austrovenus stutchburyi)

$680 \pm 45$

$\delta^{13} C=+0.5 \%$

Comment: (C.F./E.V.) as above.

Wk-1133. LN9

$690 \pm 45$

Shell (Austrovenus stutchburyi)

$\delta^{13} \mathrm{C}=+1.2 \%$

Comment: (C.F./E.V.) Dates will give archaeologists a time period in which this particular site was utilized. Dates can be compared to others in the Auckland area. Sample taken from a low-level (in terms of archaeological stratigraphy) fire scoop. This means that this could give us the earliest date for the site.

Wk 1134. LN10

$520 \pm 45$

Shell (Austrovenus stutchburyi)

$\delta^{13} C=-1.3 \%$ 
Comment: (C.F./E.V.) Sample will date the latter phase of activity on the terrace (FA41) and, combined with samples LN1 and LN9, will define the time period during which the terrace was utilized. $N . B .:$ see Fredericksen and Visser $(1989,1991)$.

Westfield site, George Bourke Drive, Tamaki (R11/898)

(Submitted by B. Sewell, Department of Conservation, Auckland)

Wk-1720. 268

Shell (Austrovenus stutchburyi)

$$
\begin{array}{r}
630 \pm 45 \\
\delta^{13} C=-0.4 \% 0 \\
540 \pm 45 \\
\delta^{13} C=-0.5 \% 0 \\
340 \pm 45 \\
\delta^{13} C=-30.1 \% 0
\end{array}
$$

Wk-1721. 269

Shell (Austrovenus stutchburyi)

Wk-2030.

Charcoal

N.B.: charcoal identified as mamaku (Cyathea medullaris).

Te Apunga o Tainui, Panama Road, Tamaki (R11/10)

(Submitted by B. Sewell, Department of Conservation, Auckland)

Wk-1722. 270

Shell (Austrovenus stutchburyi)

$680 \pm 50$

$\delta^{13} C=-0.7 \%$

Tamaki River series (R11/1506)

(Submitted 4 December 1990 by R. Foster, Department of Conservation, Auckland)

Wk-1940. ACI/R/506 F65

Shell (Austrovenus stutchburyi)

$730 \pm 35$

$\delta^{13} \mathrm{C}=+0.3 \%$

Comment: (R.F.) Dates occupation of paa site R11/1506.

Wk-1941. ACI/R/506 F33

Shell (Austrovenus stutchburyi)

$720 \pm 35$

$\delta^{13} \mathrm{C}=+0.4 \%$

Comment: (R.F.) as above.

Wk-1942. ACI/R/82

Shell (Austrovenus stutchburyi)

$670 \pm 45$

$\delta^{13} \mathrm{C}=+0.2 \%$

Comment: (R.F.) as above.

Wk-1943. ACI/R/383

Shell (Austrovenus stutchburyi)

$\mathbf{7 5 0} \pm \mathbf{4 5}$

Comment: (R.F.) as above.

$\delta^{13} \mathrm{C}=+0.9 \%$

Wk-1944. ACI/R/420

Shell (Austrovenus stutchburyi)

$680 \pm 50$

Comment: (R.F.) as above.

$\delta^{13} \mathrm{C}=+1.1 \%$

Wk-1945. ACI/R/421

Shell (Austrovenus stutchburyi)

$\mathbf{6 9 0} \pm 50$

$\delta^{13} C=+0.5 \%$ 
Comment: (R.F.) as above.

\section{Tamaki (R11/1201)}

(Submitted 4 December 1990 by B. Sewell, Department of Conservation, Auckland)

Wk-1946. $120 /-2 / 90$

$690 \pm 35$

Shell (Austrovenus stutchburyi)

$\delta^{13} \mathrm{C}=0.0 \%$

\section{Tamaki (R11/1591)}

(Submitted 21 January 1993 by D. Veart, Department of Conservation, Auckland)

Wk-2810. Sample 1

$\mathbf{7 2 0} \pm 50$

Shell (Austrovenus stutchburyi)

Wk-2811. Sample 24

$\mathbf{6 9 0} \pm 50$

Shell (Austrovenus stutchburyi)

$\delta^{13} C=-0.2 \%$

N.B.: see Bulmer (1994) for discussion and list of ${ }^{14} \mathrm{C}$ determinations from Tamaki.

Crater Hill, Waiokauri Creek, Papatoetoe (R11/602)

(Submitted 19 March 1991 by R. Foster, Department of Conservation, Auckland)

Wk-2023.

$320 \pm 45$

Charcoal

N.B.: charcoal identified as $95 \%$ Hebe twigs.

Wk-2024.

$330 \pm 45$

Charcoal

N.B.: charcoal identified as $90 \%$ Hebe twigs and $10 \%$ Pseudopanax sp. twigs.

Otahuhu paa (R11/13)

(Submitted 25 February 1991 by B. Sewell, Department of Conservation, Auckland)

Wk-2013.

$\mathbf{6 0 0} \pm 50$

Shell (Austrovenus stutchburyi)

$\delta^{13} \mathrm{C}=+0.2 \%$

Manukau sites (R11/1800 and R11/229)

(Submitted 23 June 1994 by R. Foster, Department of Conservation, Auckland)

Wk-3313. R11/1800/P13

$630 \pm 50$

Shell (Austrovenus stutchburyi)

$\delta^{13} \mathrm{C}=0.0 \%$

Comment: (R.F.) Date for site R11/1800.

Wk-3314. R11/1800/P21

Shell (Austrovenus stutchburyi)

$540 \pm 45$

Comment: (R.F.) as above.

Wk-3315. R11/229/BP1

$\delta^{13} \mathrm{C}=+1.0 \%$

Shell (Austrovenus stutchburyi) 
Comment: (R.F.) Check on traditional date for site R11/229.

Wk-3316. R11/229/EL1

$750 \pm 50$

Shell (Austrovenus stutchburyi)

$\delta^{13} \mathrm{C}=+0.4 \%$

Comment: (R.F.) Earliest occupation of R11/229.

Wk-3317. R11/229/GM1

$520 \pm 40$

Shell (Austrovenus stutchburyi)

$\delta^{13} C=-0.2 \%$

Comment: (R.F.) Check on traditional date for site R11/229.

\section{Clevedon (S11/108)}

(Submitted 21 November 1992 by A.Young, Department of Anthropology, University of Auckland)

Wk-2756. Sample 5 layer 3, sq 3-4

$\mathbf{3 2 0} \pm \mathbf{5 0}$

Charcoal

$\delta^{13} \mathrm{C}=-25.6 \%$

Comment: (A.Y.) Sample will date site to investigate association with neighboring paa.

N.B.: charcoal identified as mahoe (Melicytus ramiflorus), Olearia sp., Pittosporum sp. (eugenioides?), Coprosma sp., fivefinger (whauwhaupaku) (Pseudopanax arboreus), mangrove (Avicennia resinifera) and lancewood (horoeka) (Pseudopanax crassifolius).

Wk-2757. Sample 9 layer 2, sq 5

$360 \pm 50$

Charcoal

$\delta^{13} C=-26.1 \%$ o

Comment: (A.Y.) To help date site in order to ascertain association with neighboring paa.

N.B.: charcoal identified as Olearia sp., Coprosma sp., manuka (Leptospermum scoparium), pohutukawa (Metrosideros excelsa)/kanuka (Kunzea ericoides), tarairi (Beilschmeidia tarairi).

\section{WAIKATO}

\section{Waikorea Beach (R14/256)}

(Submitted 10 September 1990, by N. Ritchie, Department of Conservation, Hamilton)

Wk-1899. W1

$560 \pm 40$

Charcoal

$\delta^{13} C=-25.7 \%$

N.B.: charcoal was identified; no notes attached on sample constituents.

Horotiu (S14/16)

(Submitted August 1984 by B.G. McFadgen, New Zealand Historic Places Trust, Wellington)

Wk-502. Sample 1

$150 \pm 50$

Charcoal

$\delta^{13} \mathrm{C}=-26.0 \%$

Comment: (B.G.McF.) Sample will give a minimum date for "plaggen" soil on Taupo Pumice river terrace at Horotiu.

N.B.: charcoal identified as Coprosma/Pittosporum sp. (codominant) and Leptospermum sp. (subdominant).

Wk-503. Sample 2

$670 \pm 45$

Shell (Paphies australis)

\footnotetext{
$\delta^{13} C=1.9 \%$
} 
Comment: (B.G.McF.) as above. N.B.: see McFadgen (1982b).

\section{Hamilton borrow pit sites}

(Submitted 15 September 1992 by D. J. Lowe, University of Waikato, Hamilton)

Wk-2702. S14/164 Horotiu Road 1

Charcoal

Comment: (D.J.L.) Attempt to date Maori modification of soils.

N.B.: charcoal identified as small vine sp. (Metrosideros sp.), 9 pieces; mangemange (Lygodium articulatum), 1 pc; conifer twig, 1 pc; shrub sp. (Pseudopanax sp.?), 6 pc; bark fragments, 2 pc; fern leaf midribs, 2 pc; ribbonwood (Hoheria sp.), 1 pc; unidentified shrub species, 1 pc; titoki (Alectryon excelsus), 1 pc; tawa (Beilschmiedia tawa), 3 pc; totara (Podocarpus totara), 3 pc. Species 18 were bagged separately for dating. Two of the totara pieces were in the form of water-rolled pebbles, which implies that the whole sample may have inherent provenience problems.

Wk-2703. S14/164 Horotiu Road 2

Charcoal

$900 \pm 70$

$\delta^{13} C=-24.9 \%$

Comment: (D.J.L.) As above.

N.B.: charcoal identified as totara (Podocarpus totara), 4 pieces and matai (Prumnopitys taxifolia), 3 pc.

Wk-2704. S14/164 Horotiu Road 3

Charcoal

$800 \pm 50$

$\delta^{13} C=-25.1 \%$

Comment: (D.J.L.) As above.

N.B.: charcoal identified as rimu (Dacrydium cupressinum), 2 pieces; totara (Podocarpus totara), 3 pc; kahikatea (Dacrycarpus dacrydioides), 8 pc.

Wk-2705. S14/204 Kay Road 1

Charcoal

$310 \pm 150$

$\delta^{13} C=-27.4 \%$

Comment: (D.J.L.) As above.

N.B.: tawa twigs (Beilschmeidia tawa), 6 pieces; tawa, 10 pc.

Wk-2706. S15/378 Old School Road, Waipa

Charcoal

$940 \pm 100$

Comment: (D.J.L.) As above.

N.B.: charcoal identified as tawa twigs (Beilschmeidia tawa), 6 pieces; bark fragments, 3 pc; rewarewa (?) (Knightia excelsa), 2 pc.

Kawhia

(Submitted March 1978 by C. F. Pain, Geography Department, University of Papua New Guinea, Port Moresby)

Wk-31. CFP 1

$660 \pm 120$

Charcoal

$\delta^{13} C=-25.0 \%$

Comment: (C.P.) Date indicates 1) minimum age for the dune building phase prior to development of the Parangi soils, 2) time of Maori occupation in the area.

N.B.: $\delta^{13} \mathrm{C}$ value estimated. 


\section{Lake Taharoa}

(Submitted March 1978 by C. F. Pain, Geography Department, University of Papua New Guinea, Port Moresby)

Wk-33. CFP 3

Charcoal

$380 \pm 110$

$\delta^{13} C=-25.0 \%$

Comment: (C.P.) Date indicates 1) minimum age for the dune building phase prior to development of the Parangi soils, 2) time of Maori occupation in the area.

N.B.: $\delta^{13} \mathrm{C}$ value estimated. See Pain (1979).

\section{Arapuni (T15/223)}

(Submitted 29 October 1992 by D. J. Lowe, University of Waikato, Hamilton)

Wk-2736. A1

Charcoal

$940 \pm 100$

$\delta^{13} C=-26.4 \%$

N.B.: charcoal identified as matai (Prumnopitys taxifolia), 10 pieces; kaikomako (Pennantia corymbosa), $1 \mathrm{pc}$; shrub sp., $3 \mathrm{pc}$.

Wk-2737. A2

Charcoal

$1220 \pm 50$

$\delta^{13} C=-26.0 \%$

Comment: (D.J.L.) Attempt to date Maori modification of soils. Sample A2 may relate to preMaori geomorphic event.

$N . B$. : sample was unidentified wood.

Wk-2738. A3

Shell (Hyridella menziesii)

$5190 \pm 60$

$\delta^{13} \mathrm{C}=-4.7 \%$

Comment: (D.J.L.) Attempt to date Maori modification of soils indirectly, sample dates occupation at Arapuni site. Shells occur in topsoil directly overlying volcanogenic alluvium (Hopuhopu Sand Member of Taupo Pumice Alluvium) that was deposited after eruption of Taupo Tephra, 1850 BP. Dates on charcoal in this alluvium nearby confirm timing of deposition (Wk-2974-2976; D. J. Lowe, personal communication 1993). Thickness of shells is unusual, but not unknown (B. Hayward, personal communication 1993).

N.B.: shells were identified as freshwater Hyridella menziesii by B. Hayward, Auckland Museum.

\section{COROMANDEL PENINSULA/THAMES VALLEY}

\section{Te Maketu, North Coralie Bay, Great Mercury Island}

(Submitted 10 December 1976 by S. Edson, Waikato Art Museum, Hamilton)

Wk-94.

Charcoal

$410 \pm 130$

$\delta^{13} \mathrm{C}=-25.0 \%$

Comment: (S.E.) Sample derived from a large oven area associated with an extensive working floor, some $200-300 \mathrm{~m}^{2}$ of which has been seriously affected by erosion and wandering stock. Site appears to be spatially substantial but probably occupied only once.

$N . B$. : charcoal was not identified; $\delta^{13} \mathrm{C}$ value estimated. 


\section{Whangapoua Forest series}

(Submitted 17 February 1987 by L. Furey, New Zealand Forest Service, P.O. Box 39, Auckland)

Wk-968. T11/644 Area 1

Wood

$940 \pm 45$

$\delta^{13} \mathrm{C}=-28.5 \%$

Comment: (L.F.) Dating of prehistoric Maori occupation of inland terrace structure at Whangapoua, Coromandel.

N.B.: wood identified as maire branchwood (Nestigis sp.).

Wk-969. T11/636

Shell (Paphies australis)

$780 \pm 45$

$\delta^{13} C=+1.8 \%$

Wk-970. T11/643-4

Shell (Paphies australis)

$840 \pm 45$

$\delta^{13} \mathrm{C}=+3.1 \%$

Comment: (L.F.) To date open settlement occupation at Whangapoua, Coromandel.

Wk-971. T11/679-22 Area B

Shell (Paphies australis)

$850 \pm 45$

$\delta^{13} \mathrm{C}=+2.4 \%$

Comment: (L.F.) To date use of site.

Wk-972. T11/661

Shell (Paphies australis)

Wk-973. T11/644, trench 2, 4.5

Shell (Paphies australis)

$790 \pm 45$

$\delta^{13} \mathrm{C}=+2.4 \%$

Comment: (L.F.) To date open settlement (Maori) at Whangapoua, Coromandel.

Wk-974. T11/635

Shell (Paphies australis)

Wk-975. T11/648-18 G40 spit 9

Shell (Paphies australis)

$720 \pm 45$

$\delta^{13} \mathrm{C}=+2.1 \%$

Comment: (L.F.) To date open settlement occupation at Whangapoua.

\section{Kaimarama paa, Whitianga}

(Submitted 1988 by H. Larsen, Ferry Landing, RD. 1, Whitianga)

Wk-1151.

$640 \pm 45$

Shell (Paphies subtriangulatum/Austrovenus/gastropods)

$\delta^{13} \mathrm{C}=+1.0 \%$

Comment: (H.L.) Determination of occupancy date of site.

Paku, Tairua (T11/308)

(Submitted 6 December 1993 by C. Barr, Department of Conservation, Hamilton)

Wk-3100. Paku Sample 1

$710 \pm 45$

Shell (Austrovenus stutchburyi)

$\delta^{13} \mathrm{C}=+1.8 \%$ o

Comment: (C.B.) Date will provide information regarding the occupation of midden site. 
Tairua (T11/805)

(Submitted 17 September 1994 by C. Barr, Department of Conservation, Hamilton)

Wk-3385. Sample 18

Shell (Paphies australis)

Wk-3386. Sample 15

Shell (Paphies australis)
$820 \pm 45$

$\delta^{13} \mathrm{C}=+1.3 \%$

$760 \pm 50$

$\delta^{13} \mathrm{C}=+1.2 \%$

Tairua (T11/300)

(Submitted 30 June 1995 by C. Barr, Department of Conservation, Hamilton)

Wk-3952. T11/300/1

Shell (Paphies australis)

$660 \pm 50$

Wk-3953. T11/300/2

Shell (Paphies australis)

$\delta^{13} \mathrm{C}=+1.0 \%$

$680 \pm 50$

$\delta^{13} \mathrm{C}=-1.2 \%$

Whitipirorua, Onemana (T12/16)

(Submitted 13 May 1988 by L. Furey, Department of Conservation, Auckland)

Wk-1169. Square 4, layer 2

Shell (Austrovenus stutchburyi)

$870 \pm 45$

$\delta^{13} \mathrm{C}=+1.0 \%$

Wk-1515. Square 8, layer 5

Shell (Paphies australis)

$990 \pm 50$

$\delta^{13} \mathrm{C}=+0.9 \%$

N.B.: see Furey (1991). Wk-1515 submitted on 17 August 1989.

Whangamata (T12/654)

(Submitted by S. Short, Department of Anthropology, University of Auckland)

Wk-1153. Sample 1

$670 \pm 50$

Shell (Austrovenus stutchburyi)

$\delta^{13} \mathrm{C}=+1.3 \%$

Comment: (S.S.) Dating of second phase of occupation on terrace 1 at T12/654, an open settlement site at Whangamata.

Wk-1154. Sample 2

$\mathbf{7 0 0} \pm \mathbf{5 0}$

Shell (Austrovenus stutchburyi)

$\delta^{13} C=+1.8 \%$

Comment: (S.S.) Dating of initial occupation on Terrace 1 at T12/654, an open settlement at Whangamata.

Wk-1156. T12/654 sample 6

$\mathbf{7 3 0} \pm \mathbf{5 0}$

Shell (Austrovenus stutchburyi)

$\delta^{13} \mathrm{C}=+2.0 \%$

Comment: (S.S.) To date initial occupation of terrace 3 at T12/654, an open settlement site at Whangamata.

Wk-1157. T12/654 sample 11

$580 \pm 50$

Shell (Austrovenus stutchburyi)

$$
\delta^{13} C=+1.4 \%
$$


Comment: (S.S.) Dating of occupation at two adjacent terraces (5 and 6) at $\mathrm{T} 12 / 654$, an open settlement site at Whangamata.

Puriri series

(Submitted 10 August 1992 by S. Bedford and H. Allen, Department of Anthropology, University of Auckland)

Wk-2640. T12/882 Midden F Sample 1

Modern

Charcoal

$$
\delta^{13} C=-27.2 \%
$$

Comment: (S.B.) Only way of dating a now destroyed midden.

N.B.: wood identified as bark (2 species), manuka (Leptospermum scoparium), mapou (Myrsine australis), Hebe sp.

Wk-2641. T12/340 Area D2 Sample 2

Charcoal

Modern

$\delta^{13} C=-25.3 \%$

N.B.: wood identified as manuka (Leptospermum scoparium), 10 pieces; fivefinger (Pseudopanax arboreus), 1 pc; Hebe sp., 5pc; mahoe (Melicytus ramiflorus), 1 pc; Coprosma sp., 1 pc; Olearia sp, $1 \mathrm{pc}$; tawheowheo (Quintinia serrata), 2 pc.

Wk-2642. T12/885 Sq H Sample 3

Charcoal

Modern

$\delta^{13} C=-25.6 \%$

N.B.: wood identified as manuka (Leptospermum scoparium), 8 pieces; Akeake (Dodonaea viscosa), 6 pc; Pittosporum sp., 1 pc; Hebe sp., 1 pc; rangiora (Brachyglottis repanda), 1 pc.

Wk-2643. T12/882 Midden F Sample 4

Shell (Paphies australis)

$590 \pm 50$

N.B.: same prover:ience as sample Wk-2640.

Wk-2644. T12/340 Area D2 Sample 5

Shell (Austrovenus stutchburyi)

$\delta^{13} \mathrm{C}=+0.8 \%$

N.B.: same provenience as sample Wk-2641.

Wk-2645. T12/885 Sq H Sample 6

Shell (Austrovenus stutchburyi)

N.B.: same provenience as sample $\mathrm{Wk}-2642$.

Wk-2646. T12/883 Sq H Sample 7

Shell (Austrovenus stutchburyi)

Comment: (S.B.) This site is an historic Maori site which dates to $c a .1860$. However, dead shell may have been brought into the area to build up the site, rather than for consumption, hence the interest in the date of the shell.

N.B.: see Bedford and Allen (1993).

\section{Hurumoimoi paa, Kopu (T12/347)}

(Submitted 25 March 1993 by T. Doelman and H. Allen, Department of Anthropology, University of Auckland) 
Wk-2852. S1375 layer 5

$$
\begin{array}{r}
380 \pm 50 \\
\delta^{13} C=-26.0 \%
\end{array}
$$

Charcoal

Comment: (T.D./H.A.) The charcoal sample may mark the initial exploration and settlement of the area. It may show land clearance and time of occupation.

N.B.: charcoal was identified as manuka (Leptospermum scoparium), 7 pieces; Hebe sp., 12 pc; Pittosporum sp., 4 pc; fivefinger (Pseudopanax arboreus), 5 pc; unidentified shrub species, 2 pc.

Wk-2853. B1809 layer 3

Charcoal

Modern $\delta^{13} C=-26.0 \%$

Comment: (T.D./H.A.) The charcoal sample marks a single event within a prehistoric occupation. It will date a hangi [earth oven-T.H.] found during excavation and may give a time depth for the paa.

N.B.: charcoal was identified as Olearia sp., 9 pieces; Hoheria sp. (ribbonwood/lacebark), 3 pc; mangrove (Avicennia resinifera), 5 pc; akeake (Dodonaea viscosa), 1 pc; manuka (Leptospermum scoparium), $5 \mathrm{pc}$; unidentified shrub species, $1 \mathrm{pc}$.

N.B.: see Doelman (1995).

Wk-2854. B1809 layer 3 shell

Shell (Paphies australis)

$670 \pm 50$

Comment: (T.D./H.A.) as for Wk-2853.

\section{Waihou River series}

(Submitted 15 April 1993 by H. Allen, Department of Anthropology, University of Auckland)

Wk-2872. Orurukumatua paa T12/569 Sample 1/2

Shell (Marine species)

$$
\begin{array}{r}
690 \pm 50 \\
\delta^{13} C=+1.1 \% 0
\end{array}
$$

Comment: (H.A.) Will aid in reconstruction of settlement along the Waihou River.

Wk-2873. Whetukura paa T12/345 Sample 2/2 layer 2

Shell (Marine species)

$770 \pm 50$

$\delta^{13} C=+0.6 \%$

Comment: (H.A.) Comparison with nearby site of Oruarangi paa. Sample marks expansion of site to much larger defended settlement.

Wk-2874. Whetukura paa T12/345 Sample 2/2 layer 5

Shell (Marine species)

$710 \pm 50$

$\delta^{13} C=-1.0 \%$

Comment: (H.A.) Comparison with nearby site of Oruarangi paa. Sample marks initial occupation of what was to become one of the largest paa sites in the region.

Wk-2875. Turua paa T12/789

Shell (Marine species)

$\mathbf{5 5 0} \pm \mathbf{5 0}$

$\delta^{13} \mathrm{C}=+0.7 \%$

Comment: (H.A.) Comparison with other paa constructed in area. Should date first defense of site.

\section{Whetukura paa (T12/345)}

(Submitted 14 June 1993 by H. Allen, Department of Anthropology, University of Auckland) 
Wk-2949. Whetukura paa T12/345 Sample 1/1 layer 4

$$
\begin{array}{r}
210 \pm 90 \\
\delta^{13} C=-27.3 \%
\end{array}
$$

Charcoal

Comment: (H.A.) Will aid in reconstruction of settlement along the Waihou River.

N.B.: charcoal identified as mapou (Myrsine australis), putaputaweta (Carpodetus serratus), mahoe (Melicytus ramiflorus), lancewood (horoeka) (Pseudopanax crassifolius), ramarama (Lophomyrtus bullata), Dracophyllum sp., manuka (Leptospermum scoparium), unidentified shrub and bark.

Wk-2950. Whetukura paa T12/345 Sample 2/1 layer 2 Charcoal

Comment: (H.A.) Comparison with nearby site of Oruarangi paa. Samples marks expansion of site to much larger defended settlement.

N.B.: charcoal identified as akeake (Dodonaea viscosa), Hebe sp., manuka (Leptospermum scoparium), fivefinger (Pseudopanax arboreus) (whauwhaupaku), lancewood (horoeka) (Pseudopanax crassifolius), ramarama (Lophomyrtus bullata), Olearia sp., unidentified shrub.

Wk-2951. Whetukura paa T12/345 Sample 2/3 layer 5 Charcoal

$$
\delta^{13} C=\begin{array}{r}
320 \pm 90 \\
-25.4 \% \circ
\end{array}
$$

Comment: (H.A.) Comparison with nearby site of Oruarangi paa. Sample marks initial occupation of what was to become one of the largest paa sites in the region.

N.B.: charcoal identified as fivefinger (Pseudopanax arboreus) (whauwhaupaku), Pittosporum sp., Dracophyllum sp., unidentified shrub.

Pukehue paa (T12/299)

(Submitted 22 September 1993 by H. Allen, Department of Anthropology, University of Auckland)

Wk-3038. Area A, layer 2

Charcoal

Modern

$\delta^{13} C=-25.0 \%$

Comment: (H.A.) Dates the occupation of the foothills in a general comparison to the low-lying swamp paa. A settlement movement may be defined.

N.B.: charcoal identified as manuka (Leptospermum scoparium), Hebe sp., fivefinger (Pseudopanax arboreus) (whauwhaupaku), Dracophyllum sp. See Allen et al. (1994).

\section{Raupa, Ohinemuri River, Paeroa (T13/13)}

(Submitted 22 March 1991 by N. Prickett, Auckland Institute and Museum, Auckland)

Wk-2039.

Shell (Paphies australis)

$510 \pm 50$

Wk-2040.

$\delta^{13} C=0.0 \%$

Shell (Paphies/Austrovenus)

$620 \pm 50$

Wk-2041.

$\delta^{13} \mathrm{C}=+0.7 \%$

Charcoal

Modern

$\delta^{13} \mathrm{C}=-27.9 \%$

N.B.: charcoal was identified Coprosma sp., 8 identifications. See Prickett (1992). 


\section{BAY OF PLENTY}

Tauwhare 2, Whakatane (W15/35)

(Submitted 7 June 1990, by K. Jones, Department of Conservation, Wellington)

Wk-1765. Tauwhare 2

$670 \pm 45$

Shell (Paphies australis)

$\delta^{13} \mathrm{C}=+1.3 \%$

Comment: (K.J.) Date gives maximum age for principal surviving defensive earthworks of a major paa in the Whakatane area.

N.B.: see Bowers and Jones (1991).

Papamoa

(Submitted 28 September 1992 by D. Kahotea, Te Ongaonga Rd, RD1, Tauranga)

Wk-2713. Sample 2

$800 \pm 50$

Shell (Paphies australis)

Comment: (D.K.) Important for cultural layer date.

Wk-2714. Sample 2 lens B

$\mathbf{5 4 0} \pm \mathbf{5 0}$

Shell (Paphies australis)

$\delta^{13} \mathrm{C}=+1.3 \%$

Comment: (D.K.) as above.

Wk-2715. Area 2 knoll

Shell (Paphies australis)

Comment: (D.K.) as above.

Wk-2716. A-sample in wall

$830 \pm 60$

Shell (Paphies australis)

Comment: (D.K.) as above.

Wk-2717. R14, T2 S1

$\mathbf{6 5 0} \pm \mathbf{5 0}$

Shell (Paphies australis)

$\delta^{13} \mathrm{C}=+1.5 \%$

Comment: (D.K.) as above.

\section{Royal Palm Beach, Papamoa (U14/1717)}

(Submitted 31 January 1995 by R. McGovern-Wilson, SouthernArc, P.O. Box 9004, Dunedin)

Wk-3623. RPB/1 Area 2

$690 \pm 50$

Shell (Paphies subtriangulatum)

$\delta^{13} \mathrm{C}=+2.2 \%$

Comment: (R.McG.-W.) The midden from which this sample derived is a concentrated area within a large $\left(\mathrm{ca} .400 \mathrm{~m}^{2}\right)$ midden scatter, and is one of a number of dates submitted to detail the period of coastal activity in the vicinity of Papamoa.

Wk-3630. RPB/2 Area A midden 5

$\mathbf{7 6 0} \pm 50$

Shell (Paphies subtriangulatum)

$\delta^{13} \mathrm{C}=+1.8 \%$

Comment: (R.McG.-W.) These date a large midden scatter and appear to date to a significantly earlier period of Papamoa than previously recorded. 
Wk-3631. RPB/3 Area A midden 13

$820 \pm 50$

Shell (Paphies subtriangulatum)

$\delta^{13} C=+1.0 \%$

Comment: (R.McG.-W.) as above.

Wk-3632. RPB/4 Area A midden 15 layer 3

Shell (Paphies subtriangulatum)

$760 \pm 50$

Comment: (R.McG.-W.) as above.

Wk-3633. RPB/5 Area B midden 3

$\mathbf{7 3 0} \pm \mathbf{5 0}$

Shell (Paphies subtriangulatum)

$\delta^{13} C=+1.7 \%$

Comment: (R.McG.-W.) as above.

Wk-3634. RPB/6 Area E

Shell (Paphies subtriangulatum)

$810 \pm 50$

Comment: (R.McG.-W.) as above.

Wk-3635. RPB/7 Area G midden 2

Shell (Paphies subtriangulatum)

$\delta^{13} \mathrm{C}=+1.8 \%$

Comment: (R.McG.-W.) as above.

\section{Papamoa (U14/2841)}

(Submitted 25 October 1995 by C. Fredericksen, P.O. Box 91206, Auckland)

Wk-4189. ${ }^{14} \mathrm{C} 1$

Shell (Paphies subtriangulatum)

$800 \pm 50$

$\delta^{13} \mathrm{C}=+1.3 \%$

Comment: (C.F.) Dates first use of the terrace. Eastern Bay of Plenty culture history.

Wk-4190. ${ }^{14} \mathrm{C} 3$

Shell (Paphies subtriangulatum)

$\mathbf{7 3 0} \pm \mathbf{5 0}$

$\delta^{13} C=+1.2 \%$

Comment: (C.F.) Date of infilling of "bin pit". Eastern Bay of Plenty culture history.

Wk-4191. ${ }^{14} \mathrm{C} 4$

Shell (Struthiolaria papulosa)

Comment: (C.F.) Dates final stage of terrace use. Eastern Bay of Plenty culture history.

Wk-4192. ${ }^{14} \mathrm{C} 5$

Shell (Paphies subtriangulatum)

$760 \pm 50$

Comment: (C.F.) as above.

\section{Tupitika paa, Whakatane (W15/9)}

(Submitted 2 June 1995 by R. McGovern-Wilson, SouthernArc, P.O. Box 9004, Dunedin)

Wk-3750. TP/1

Shell (Paphies australis)

Comment: (R.McG.-W.) The rua [subterranean storage pit-T.H.] from which these samples derive was being used for dumping midden in. The dates will provide an indication of when the paa was being occupied. 
Wk-3754. TP/2

Shell (Paphies australis)

$660 \pm 50$

$\delta^{13} \mathrm{C}=+1.1 \%$

Comment: (R.McG.-W.) as above.

Athenree (U13/46)

(Submitted 2 June 1995 by R. McGovern-Wilson, SouthernArc, P.O. Box 9004, Dunedin)

Wk-3751. WA/1

Shell (Paphies subtriangulatum)

$660 \pm 50$

$\delta^{13} \mathrm{C}=+1.1 \%$

Comment: (R.McG.-W.) The features from which these samples derive are from an early phase of the paa development and will date, or approximate, when the paa was built.

Wk-3755. WA/2

Shell (Paphies subtriangulatum)

$720 \pm 50$

$\delta^{13} \mathrm{C}=+1.3 \%$

Comment: (R.McG.-W.) as above.

N.B.: See Phillips and Allen (1996) for further dating and discussion.

Robbie's Midden, Tarawera River, East of Rangitaiki Plains (V15/1209)

(Submitted 2 June 1995 by R. McGovern-Wilson, SouthernArc, P.O. Box 9004, Dunedin)

Wk-3752. MP/1

Shell (Paphies subtriangulatum)

$600 \pm 50$

$\delta^{13} \mathrm{C}=+1.5 \%$

Comment: (R.McG.-W.) It is predicted that this site may be from the early prehistoric period and will mark early settlement on the Rangitaiki Plains.

\section{Uretara Island, Ohiwa Harbour (W15/363)}

(Submitted 2 June 1995 by R. McGovern-Wilson, SouthernArc, P.O. Box 9004, Dunedin)

Wk-3753. MP/2

Shell (Austrovenus stutchburyi)

$\mathbf{6 0 0} \pm 50$

$\delta^{13} \mathrm{C}=+0.5 \%$

Comment: (R.McG.-W.) There are many shell middens around the Ohiwa Harbour-this may be one of the earlier ones; it is sitting near the surface of a Taupo ash fall.

\section{Kawerau sites}

(Submitted 21 April 1990, by I. T. Lawlor, Taiapa Road, Waimauku)

Wk-1740. 171\#1 (Site V16/211)

Charcoal

$460 \pm 55$

$\delta^{13} C=-29.0 \%$

Comment: (I.T.L.) Age estimate of occupation of site V16/211, Kawerau, Bay of Plenty.

N.B.: charcoal identified as mahoe (Melicytus sp., ramiflorus or lanceolatus).

Wk-1741. 774 (adjacent to site V16/243)

Charcoal

$\begin{aligned} & 400 \pm 55 \\ \delta^{13} C= & -27.8 \% 0\end{aligned}$

Comment: (I.T.L.) Age estimate for valley gardening adjacent to site V16/243, Kawerau, Bay of Plenty.

N.B.: wood identified as Hebe sp. 
Wk-1742. 1070 (Site V16/220)

$360 \pm 55$

Charcoal

$\delta^{13} C=-26.4 \%$

Comment: (I.T.L.) Age estimate for occupation of site V16/220. Comparative date for adjacent shell midden age estimate.

N.B.: wood identified as Hebe sp. and manuka (Leptospermum scoparium).

Wk-1743. 1278 (Site V16/220)

Charcoal

$$
\begin{array}{r}
520 \pm 80 \\
\delta^{13} C=-26.4 \% 0
\end{array}
$$

Comment: (I.T.L.) Age estimate of occupation of site V16/220. Comparative date for adjacent shell midden and hangi age estimates.

N.B.: wood is $95 \%$ tree fern trunk (ponga, Cyathea dealbata) and tanekaha or toatoa (Phyllocladus) sp.

Wk-1744. 1514 (Site V16/219)

$370 \pm 55$

Charcoal

$\delta^{13} \mathrm{C}=-25.5 \%$

Comment: (I.T.L.) Age estimate of occupation of site V16/219. Postdates use of large kumara storage pit.

N.B.: charcoal is kanuka (Kunzia ericoides).

Wk-1745. 1572 (Site V16/219)

$350 \pm 55$

Charcoal

$\delta^{13} C=-29.0 \%$

Comment: (I.T.L.) Age estimate of occupation of site V16/219. Use of large kumara storage pit.

N.B.: wood is ponga (Cyathea dealbata).

\section{Hamurana, Lake Rotorua (U15/35)}

(Submitted 13 May 1988 by D. Kahotea, Department of Social Anthropology, University of Waikato)

Wk-1218.

Charcoal

Modern

Wk-1219.

Charcoal

$\delta^{13} \mathrm{C}=-27.4 \%$

Wk-1220.

Charcoal

Wk-1221.

Charcoal

$230 \pm 125$

Wk-1222.

Charcoal

$\delta^{13} C=-26.6 \%$

$\mathbf{2 8 0} \pm \mathbf{5 0}$

$\delta^{13} C=-26.5 \%$

Modern

$\delta^{13} \mathrm{C}=-32.5 \%$

Modern

$\delta^{13} C=-27.1 \%$

N.B.: all dates on unidentified charcoal.

HAWKES BAYIEAST COAST

Tolaga Bay (Z17/211)

(Submitted December 1987 by K. Jones, Department of Conservation, Wellington) 
Wk-1147. Z17/211 TGB 4

$350 \pm 125$

Charcoal

$\delta^{13} C=-25.2 \%$

Comment: (K.J.) A maximum age for defensive ditch and bank of paa Z17/211, Tolaga Bay, New Zealand.

N.B.: Wood is Hebe and Coprosma sp. twigs and fern stems.

Wk-1148. TGB 10

$370 \pm 70$

Charcoal

$\delta^{13} C=-24.0 \%$

Comment: (K.J.) Minimum age for paa fortification on East Coast, New Zealand.

N.B.: wood is Pseudopanax sp., tawa (Beilschmeidia tawa), Hedycarya sp., Coprosma twigs, fern stems, rangiora (Brachyglottis repanda). See Jones (1990).

\section{Hawkes Bay series}

(Submitted 11 December 1990 by M. Allen, Department of Anthropology, University of California at Los Angeles)

\section{Heipipi paa (V20/9-14)}

Wk-1956. Unit 1A

$730 \pm 45$

Shell (Paphies subtriangulatum)

$\delta^{13} \mathrm{C}=-0.1 \%$

Comment: (M.A.) Date is for a shell midden directly associated with a traditionally important and early paa in Hawkes Bay.

Wk-1957. Unit 2

Shell (Paphies subtriangulatum)

$680 \pm 45$

$\delta^{13} \mathrm{C}=0.4 \%$

Comment: (M.A.) as above.

Wk-1958. Unit 4

Shell (Paphies subtriangulatum)

$700 \pm 45$

$\delta^{13} \mathrm{C}=-0.2 \%$

Comment: (M.A.) as above.

Wk-3048.

$880 \pm 50$

Shell (unknown)

$\delta^{13} \mathrm{C}=0.8 \%$

N.B.: Wk-3048 submitted 28 October 1993 by E. Pishief, 3 Hulcarere Road, Gisborne.

\section{Matanginui paa, Waimarama Beach (V22/95)}

Wk-1959. Unit 1

Shell (Paphies subtriangulatum)

$500 \pm 40$

$\delta^{13} \mathrm{C}=+1.3 \%$

Comment: (M.A.) Date is for occupation of a traditionally important paa at Waimarama, Hawkes Bay.

Wk-1960. Unit 2

$520 \pm 40$

Shell (Paphies subtriangulatum)

$\delta^{13} \mathrm{C}=+1.9 \%$

Comment: (M.A.) as above.

Wk-1961. Unit 3

Shell (Paphies subtriangulatum)

$480 \pm 40$

$\delta^{13} \mathrm{C}=+1.9 \%$ 
Comment: (M.A.) as above.

Motukumara paa, Lake Oingo (V21/45)

Wk-1962. Unit 1, postholes 2-4

Charcoal

$\delta^{13} C=-25.8 \%$

Comment: (M.A.) Dating midden layer with much charcoal associated with three postholes full of charcoal. The charcoal does not directly date the posts as it comprises many species. Provides a minimum age for fill and midden used to build up major defense on an inland freshwater paa.

N.B.: charcoal species identified as bark, sevenfinger, ribbonwood (Hoheria sp.), Hebe sp., Coprosma sp., mahoe (Melicytus ramiflorus), ngaio (Myoporum laetum), fivefinger (Pseudopanax arboreus), and other shrubs.

Wk-1963. Hangi feature 1

Charcoal

Modern

$\delta^{13} C=-25.4 \%$

Comment: (M.A.) Hangi sits on terrace and midden fill-postdates terrace construction on a strongly defended paa on a small freshwater lake in inland Hawkes Bay.

N.B.: charcoal identified as lancewood twigs (Pseudopanax crassifolius), sevenfinger, karaka twig (Corynocarpus laevigatus). Date from a hangi on rim of terraced paa.

Wk-1964.

Modern

Charcoal

$$
\delta^{13} C=-24.0 \%
$$

Comment: (M.A.) Date for burning off of bracken fern prior to paa construction on inland freshwater lake in Hawkes Bay.

N.B.: charcoal identified as $80 \%$ bracken fern, sevenfinger, pate (Scheffliera digitata).

Manawarakau paa, Kairakau beach (V22/267 and V22/268)

Wk-1965. Unit 1 layer C

Shell (Lunella smaragda)

$560 \pm 50$

$\delta^{13} \mathrm{C}=+1.9 \%$

Comment: (M.A.) Bottom layer of shell midden on slope below terrace of important coastal paa in Hawkes Bay.

Wk-1966. Unit 2

$\mathbf{5 9 0} \pm \mathbf{4 0}$

Shell (Lunella smaragda)

$\delta^{13} \mathrm{C}=+2.1 \%$

Comment: (M.A.) Shell midden postdates a defensive terrace on an important coastal paa in Hawkes Bay.

Wk-1967. Unit 3

Shell (Lunella smaragda)

$680 \pm 40$

$\delta^{13} C=+2.1 \%$

Comment: (M.A.) Midden below likely house terrace on important coastal paa of Hawkes Bay.

Poto paa, Ahuriri (V21/9)

Wk-2130. Unit $1,0-10 \mathrm{~cm}$

$660 \pm 55$

Shell (Austrovenus stutchburyi)

$\delta^{13} C=+0.1 \%$

Comment: (M.A.) Minimum age for defensive bank on headland paa above inner harbor of Hawke's Bay. 
Wk-2131. Unit 1, layer D

$790 \pm 50$

Shell (Austrovenus stutchburyi)

$\delta^{13} \mathrm{C}=+0.9 \%$

Comment: (M.A.) as above.

Koutouroa paa, Wharerangi district, Ahuriri (V21/26)

Wk-2132. No. 80 Unit 1

$750 \pm 50$

Shell (Austrovenus stutchburyi)

$\delta^{13} C=0.9 \%$

Comment: (M.A.) Date for shell midden on paa site along former inner harbor of Hawke's Bay.

Wk-2133. No. 81 Unit 2

$840 \pm 45$

Shell (Austrovenus stutchburyi)

$\delta^{13} C=-0.6 \%$

Comment: (M.A.) as above.

Wk-2134. No. 82 Unit 3

$710 \pm 45$

Shell (Austrovenus stutchburyi)

Comment: (M.A.) as above.

Te Mingi paa, Tutaekuri River (V21/49)

Wk-2135. Unit 1, No 3

$710 \pm 40$

Shell (Paphies subtriangulatum)

$\delta^{13} C=+0.1 \%$

Comment: (M.A.) Date for midden high on slope of large paa on the Tutaekuri river, Hawke's Bay.

Mangawharau paa, Waimarama Beach (W22/152)

Wk-2136. Unit 1, No 58

$640 \pm 50$

Shell (Haliotis sp.)

$\delta^{13} \mathrm{C}=+1.3 \%$

Comment: (M.A.) Midden on paa site at Waimarama beach, Hawke's Bay.

Wk-2137. Unit 2, No 59

Shell (Haliotis sp.)

$710 \pm 50$

$\delta^{13} C=+1.6 \%$

Comment: (M.A.) Paua cache just outside of defensive bank at paa at Waimarama beach.

Wk-2138. Unit 3, No 61

$570 \pm 45$

Shell (Paphies subtriangulatum)

$\delta^{13} C=+1.7 \%$

Comment: (M.A.) Midden on paa site at Waimarama beach, Hawke's Bay.

Otatara paa, Taradale (V21/41)

(Submitted 29 October 1991 by P. Bain and E. Pishief, Department of Conservation, Napier)

Wk-2273. Sample 1

$810 \pm 45$

Shell (unknown)

$\delta^{13} \mathrm{C}=+0.2 \%$

Comment: (P.B.) Otatara paa Historic Reserve is described by Eileen Fox as the largest and most impressive of the many paa in Hawkes Bay. It is over 40 ha in size. It has a detailed traditional and archaeological history. It used to be two paa, a higher one called Hikurangi and a lower one called Otatara that has largely been quarried away. Traditionally, this site is known as the paa from which 
Taraia gained the foothold that enabled Ngati Kahungunu to become the dominant $i w i$ in Hawke's Bay.

Wk-2274. Sample 2

Shell (unknown)

Comment: (P.B.) as above.

Te Ihu O Te Rei (V21/28)

(Submitted 21 August 1991 by P. Bain, Department of Conservation, Gisborne)

Wk-2306. Sample 1

Shell (mixture including Venerupis largillierti)

$660 \pm 45$

$\delta^{13} \mathrm{C}=-0.4 \%$

Comment: (P.B.) Site uncovered during bulldozing work. Site traditionally important to Ngati Kahungunu. Located on one of a number of islands in Te Whanganui a Orutu lagoon.

Wk-2307. Sample 2

Shell (Paphies australis and Venerupis largillierti)

Comment: (P.B.) as above.

Parangatau (V23/21)

(Submitted 12 June 1992 by P. Bain, Department of Conservation, Gisborne)

Wk-2515. Midden V23/21 Square D (layer 6)

Shell (Austrovenus stutchburyi)

$1040 \pm 60$

$\delta^{13} C=-0.4 \%$

Comment: (P.B.) Parangatau area is extremely significant in traditional stories. Archaic artifacts collected in 1940s from the area.

\section{WELLINGTON}

\section{Mana Island (R26/141)}

(Submitted 13 June 1990 by L. M. Horwood, Wanganui Regional Museum, Wanganui)

Wk-1755. 141/6

Shell (Paphies subtriangulatum)

$820 \pm 45$

$\delta^{13} \mathrm{C}=+1.21 \%$

Comment: (M.H.) Initial human occupation at northern end of site R26/141, Mana Island, New Zealand.

\section{Paekakariki (R26/255)}

(Submitted 8 June 1990 by B. G. McFadgen, Department of Conservation, Wellington)

Wk-1756. Paek M1

Shell (Paphies subtriangulatum)

$680 \pm 35$

$\delta^{13} \mathrm{C}=+1.2 \%$

Comment: (B.G.McF.) Provides maximum age for "Taupo dune" and close date for shell midden.

Wk-1757. Paek M2

$610 \pm 70$

Shell (Paphies subtriangulatum)

$\delta^{13} C=1.4 \%$ 
Comment: (B.G.McF.) Provides a minimum date for the formation of a foredune containing beds of lapilli-sized Taupo Pumice and a close date for a Maori occupation.

N.B.: see McFadgen (in press).

\section{NELSONIMARLBOROUGH}

\section{Awaroa Inlet (N26/18)}

(Submitted 17 August 1990 by I. Barber, Department of Anthropology, University of Otago)

Wk-1827.

$430 \pm 60$

Charcoal

$\delta^{13} C=-28.4 \%$

N.B.: charcoal identified as mahoe (Melicytus ramiflorus), fivefinger (Pseudopanax arboreus), kamahi (Weinmannia sp.), Olearia sp., rata (Metrosideros sp.) and beech (Notofagus sp.) fragments.

Wk-2094.

Charcoal

$$
\begin{array}{r}
460 \pm 50 \\
\delta^{13} C=-26.8 \%
\end{array}
$$

N.B.: charcoal identified as mahoe (Melicytus ramiflorus), mapou (Myrsine australis), Coprosma sp., akeake (Dodonaea viscosa), kanuka (Kunzia ericoides), Dracophylum sp., Olearia sp., Pittosporum sp., bark of unidentified species. Submitted by I. Barber, 5 June 1991.

Wk-2869. Spit 3

Shell (Austrovenus stutchburyi)

$800 \pm 40$

Wk-2870. Spit 3

Shell (Paphies subtriangulatum)

N.B.: Wk-2869 and -2870 submitted by T. Higham, Radiocarbon Dating Laboratory, University of Waikato.

\section{Sawpit Point, Awaroa Inlet (N26/214)}

(Submitted 6 December 1994 by I. Barber, Department of Anthropology, University of Otago)

Wk-3099. C14-15/SPA 122D

$800 \pm 50$

Shell (Paphies australis)

\section{Bark Bay (N26/16)}

(Submitted 2 April 1993 by T. Higham, Radiocarbon Dating Laboratory, University of Waikato)

Wk-2863. Bark Bay 3A Sample 1

Shell (Paphies australis)

Wk-2866. Bark Bay 3A Sample 2

Shell (Austrovenus stutchburyi)

Wk-2867. Bark Bay 11/13 Sample 3

Shell (Austrovenus stutchburyi)

Wk-2868. Bark Bay 11/13 Sample 4

Shell (Paphies subtriangulatum)
$840 \pm 45$

$\delta^{13} \mathrm{C}=+2.0 \%$

$800 \pm 50$

$\delta^{13} \mathrm{C}=+1.0 \%$

$\mathbf{7 7 0} \pm 40$

$\delta^{13} C=+1.2 \%$

$820 \pm 45$

$\delta^{13} \mathrm{C}=+1.9 \%$ 
Appleby (N27/118)

(Submitted 1 November 1991 by I. Barber, Department of Anthropology, University of Otago)

Wk-2278.

Shell (Austrovenus stutchburyi)

$770 \pm 45$

$\delta^{13} C=+0.2 \%$

Comment: (I.B.) Clarification of chronology of settlement and associated horticulture on the Waimea plain (i.e., pre-European settlement).

Waimea Plains (N27/122)

(Submitted 5 September 1990 by B. G. McFadgen, Department of Conservation, Wellington)

Wk-1776.

Charcoal

$360 \pm 50$

$\delta^{13} C=-26.1 \%$

N.B.: wood identified as charcoal from matai bark (Prumnopitys taxifolia).

WESTLAND

\section{Okuru series}

(Submitted 2 April 1991 by R. Hooker, Department of Conservation, Hokitika)

Wk-2043. F37/8 Okuru 1

Shell (Paphies subtriangulatum)

$830 \pm 40$

Wk-2044. F37/8 Okuru 2

Shell (Paphies subtriangulatum)

$\delta^{13} \mathrm{C}=1.3 \%$

Wk-2045. F37/7 Okuru 3

Shell (Paphies subtriangulatum)

$790 \pm 40$

$\delta^{13} C=1.3 \%$

Wk-2046. F37/19 Okuru 4

Shell (Paphies subtriangulatum)

$920 \pm 40$

$\delta^{13} \mathrm{C}=1.2 \%$

$870 \pm 50$

Wk-2047. F37/17 Okuru 5

Shell (Paphies subtriangulatum)

$\delta^{13} \mathrm{C}=1.3 \%$

N.B.: see Hooker (1986).

Arawata River Mouth (E37/5)

(Submitted 9 February 1989 by R. Hooker, Department of Conservation, Hokitika)

Wk-1388. E37/5 A south side Arawata River Mouth

Shell (Paphies subtriangulatum)

$810 \pm 50$

$\delta^{13} C=1.2 \%$

Comment: (R.H.) Dates Maori occupation at mouth of Arawata River.

Jackson Bay (E37/4)

(Submitted 9 February 1989 by R. Hooker, Department of Conservation, Hokitika)

Wk-1389. E37/4A Sea front

Charcoal 
Comment: (R.H.) Dates Maori occupation at Jackson Bay, South Westland. Sample is wooden stake from similar context.

\section{Seacombe Creek, Jackson Bay (E37/14)}

(Submitted 9 February 1989 by R. Hooker, Department of Conservation, Hokitika)

Wk-1390. E37/14A North side of creek

$410 \pm 50$

Charcoal

$\delta^{13} C=-29.0 \%$

Comment: (R.H.) Dates Maori occupation of Jackson Bay site E37/14, beside Seacombe Creek.

$N . B .:$ no species given with charcoal identification in submission forms for Wk-1388 to 1390 inclusive, but charcoal was identified by $\mathrm{R}$. Wallace.

Big Bay (D39/7)

(Submitted in 1989 by R. Hooker, Department of Conservation, Hokitika)

Wk-1167. D39/7/5

Shell (Paphies subtriangulatum)

$960 \pm 45$

$\delta^{13} \mathrm{C}=+1.7 \%$

Comment: (R.H.) Date of Maori settlement at Big Bay.

Wk-1168. D39/7/6

Shell (Paphies and Turbo smaragda)

$900 \pm 45$

$\delta^{13} \mathrm{C}=+2.4 \%$

Comment: (R.H.) Date of Maori occupation at Big Bay.

\section{CANTERBURY}

Panau, Banks Peninsula (N36/72)

(Submitted 15 June 1992 by C. Jacomb, Canterbury Museum, Christchurch)

Wk-2566. Pan/1 (layer 2a)

Charcoal

$$
\delta^{13} C=\begin{gathered}
\text { Modern } \\
-27.0 \% 0
\end{gathered}
$$

N.B.: saltmarsh ribbonwood (Plagianthus divaricatus), 6 pieces; Coprosma sp., 3 pc; fivefinger (Pseudopanax arboreus), 6 pc; akeake (Dodonaea viscosa), 2 pc; mapou (Myrsine australis), 4 pc; Dracophyllum sp., 2 pc.

Wk-2567. Pan/2 (layer 2c)

Charcoal

$$
\delta^{13} C=\begin{array}{r}
380 \pm 55 \\
-25.3 \%
\end{array}
$$

N.B.: saltmarsh ribbonwood (Plagianthus divaricatus), 8 pieces; Coprosma sp., 2 pc; Pseudopanax sp., 2 pc; Hebe sp., 2 pc; Pittosporum sp., 2 pc; Melicytus ramiflorus, 3 pc; akeake (Dodonaea viscosa), 2 pc; Myrsine australis, 3 pc.

Wk-2569. Pan/4 (layer 2c)

Charcoal

$600 \pm 45$

$\delta^{13} C=-24.7 \%$

N.B.: saltmarsh ribbonwood (Plagianthus divaricatus), 4 pieces; akeake (Dodonaea viscosa), 4 pc; matagouri (Discaria toumatou), 1 pc; Olearia sp., 7 pc.

Wk-2570. Pan/5 (layer 2b)

Charcoal

$\delta^{13} C=\begin{array}{r}640 \pm 50 \\ -24.5 \%\end{array}$ 
N.B.: saltmarsh ribbonwood (Plagianthus divaricatus), 5 pieces; Coprosma sp., 5 pc; Pseudopanax sp., 2 pc; akeake (Dodonaea viscosa), 3 pc; mapou (Myrsine australis), 2 pc.

Wk-2571. Pan/6 (layer 2c)

Charcoal

$$
\begin{aligned}
& \text { Modern } \\
& \delta^{13} C=-26.2 \% 0
\end{aligned}
$$

N.B.: saltmarsh ribbonwood (Plagianthus divaricatus), 20 pieces; Coprosma sp., 2 pc; akeake (Dodonaea viscosa), 2 pc. See Jacomb (1995).

\section{Killermont (H39/19)}

(Submitted 1990-1993 by T. Higham, Radiocarbon Dating Laboratory, University of Waikato)

Wk-2783. KLM 6

Charcoal

$640 \pm 35$

Wk-2991. KLM 62

$\delta^{13} C=-25.3 \%$

Charcoal

$\mathbf{6 3 0} \pm \mathbf{4 0}$

$\delta^{13} C=-24.8 \%$

Wk-2916. KLM 45

$660 \pm 45$

Charcoal

$\delta^{13} C=-25.5 \%$

N.B.: all Killermont charcoal identified as Olearia sp., Hebe sp., Archeria traversii, Coprosma sp., Pittosporum sp., mapou (Myrsine australis), matagouri (Discaria toumatou) and one other unknown shrub species.

\section{OTAGO/SOUTHLAND}

\section{Pleasant River (J43/1)}

(Submitted 1990-1993 by T. Higham, Radiocarbon Dating Laboratory, University of Waikato)

Wk-2507. Area 1 layer 2 B1 F5

Shell (Amphibola crenata)

Wk-2741. Area D layer 4

Moa eggshell

Wk-2753. Area 1 B1

Shell (Austrovenus stutchburyi)

$$
\begin{array}{r}
1180 \pm 45 \\
\delta^{13} C=+1.2 \% 0 \\
650 \pm 45 \\
\delta^{13} C=-12.1 \% 0 \\
910 \pm 45 \\
\delta^{13} C=+0.4 \% 0 \\
650 \pm 45 \\
\delta^{13} C=-14.0 \% 0 \\
590 \pm 40 \\
\delta^{13} C=-14.2 \% 0 \\
600 \pm 45 \\
\delta^{13} C=-13.9 \% \\
1120 \pm 45 \\
\delta^{13} C=+0.8 \% 0
\end{array}
$$

Wk-2758. Area D layer 4

Moa eggshell

Wk-2759. Area D layer 4

Moa eggshell

Wk-2760. Area D layer 4

Moa eggshell

Wk-2761. Area D layer 4

Shell (Austrovenus stutchburyi)

Wk-2762. Area D layer 4

Shell (Paphies subtriangulatum)

$1110 \pm 45$
$\delta^{13} C=+1.9 \%$ 
Wk-2763. Area D layer 3

Shell (Austrovenus stutchburyi)

Wk-2764. Area D layer 3

Shell (Paphies australis)

Wk-2765. Area D layer 3

Moa eggshell

Wk-2771. Area D layer 3

Shell (Cookia sulcata)

Wk-2772. Area D layer 4

Shell (Paphies australis)

Wk-2789. PRD-7 Area D layer 4

$$
\begin{array}{r}
920 \pm 45 \\
\delta^{13} C=+0.2 \% 0 \\
\mathbf{7 9 0} \pm \mathbf{4 5} \\
\delta^{13} C=+1.7 \% 0 \\
\mathbf{6 0 0} \pm \mathbf{4 5} \\
\delta^{13} C=-12.2 \% \\
\mathbf{7 4 0} \pm \mathbf{4 5} \\
\delta^{13} C=+1.3 \% \\
\mathbf{7 8 0} \pm \mathbf{4 5} \\
\delta^{13} C=+1.7 \% 0 \\
\mathbf{5 5 0} \pm \mathbf{9 0} \\
\delta^{13} C=-26.3 \%
\end{array}
$$

N.B.: charcoal identified as matagouri (Discaria toumatou), 13 pieces; Pittosporum sp., 4 pc; Muehlenbeckia sp., 6 pc; Coprosma sp., 1 pc; shrub sp., 1 pc.

Wk-2790. PRD-14 Area D layer 3

Charcoal

$$
\begin{array}{r}
700 \pm 90 \\
\delta^{13} C=-27.9 \%
\end{array}
$$

N.B.: charcoal identified as Muehlenbeckia sp., 10 pieces; Coprosma sp., 4 pc; matagouri (Discaria toumatou), 6 pc; saltmarsh ribbonwood (Plagianthus divaricatus), 5 pc; Olearia sp., 3 pc.

Wk-2851. Area 1 layer 2 B1 F5

Shell (Austrovenus stutchburyi)

$970 \pm 35$

$\delta^{13} \mathrm{C}=+0.4 \%$

N.B.: see Higham 1993.

\section{Pleasant River (J43/1)}

(Submitted 14 December 1994, by I. W. G Smith, Department of Anthropology, University of Otago)

Wk-3508. PLR-1100

$880 \pm 40$

Shell (Austrovenus stutchburyi)

$$
\delta^{13} C=+0.4 \%
$$

Comment: (I.S.) Dates horizon overlying moa butchery.

Wk-3509. PLR-1101

$760 \pm 40$

Shell (Austrovenus stutchburyi)

$\delta^{13} \mathrm{C}=+1.0 \%$

Comment: (I.S.) Dates horizon overlying evidence of moa hunting.

Wk-3510. PLR-1102

$\mathbf{7 2 0} \pm \mathbf{4 0}$

Shell (Austrovenus stutchburyi)

$\delta^{13} \mathrm{C}=+0.5 \%$

Comment: (I.S.) Dates evidence of primary moa butchery.

Shag River Mouth (J43/2)

(Submitted 1990-1993 by T. Higham, Radiocarbon Dating Laboratory, University of Waikato)

Wk-2362. L4 G8

Shell (Austrovenus stutchburyi)

$1010 \pm 50$

$\delta^{13} C=+1.3 \%$ 。 
Wk-2367. L4 G8

Shell (Amphibola crenata)

$1160 \pm 50$

Wk-2410. L4 F7

Shell (Austrovenus stutchburyi)

Wk-2411. L4 F7

Shell (Austrovenus stutchburyi)

Wk-2412. L4 F7

Shell (Austrovenus stutchburyi)

Wk-2416. L5 E5

Moa eggshell

Wk-2417. L6 F2/E2

Moa eggshell

Wk-2440. L4 J5

Shell (Austrovenus stutchburyi)

Wk-2441. L4 J5

Shell (Austrovenus stutchburyi)

Wk-2508. L4 H8

Shell (Austrovenus stutchburyi)

Wk-2589. L5 E5

Moa eggshell

Wk-2604. L8 13/I4

Moa eggshell

Wk-2632. L4 J5

Shell (Paphies australis)

Wk-2633. L4 J5

Shell (Amphibola crenata)

Wk-2751. L4 F7

Shell (Austrovenus stutchburyi)

Wk-2752. L4 J5

Shell (Austrovenus stutchburyi)

Wk-2856. L4 J5

Shell (Austrovenus stutchburyi)

Wk-2857. L4 J5

Shell (Austrovenus stutchburyi)

$$
\delta^{13} C=+1.3 \%
$$

$1020 \pm 50$

$\delta^{13} \mathrm{C}=+1.5 \%$

$990 \pm 45$

$\delta^{13} \mathrm{C}=+0.8 \%$

$980 \pm 45$

$\delta^{13} \mathrm{C}=+1.2 \%$

$600 \pm 50$

$\delta^{13} \mathrm{C}=-15.2 \%$

$560 \pm 45$

$\delta^{13} C=-15.0 \%$

$1050 \pm 50$

$\delta^{13} C=+0.7 \%$

$1070 \pm 45$

$\delta^{13} \mathrm{C}=+1.0 \%$

$1060 \pm 45$

$\delta^{13} C=-0.7 \%$

$600 \pm 50$

$\delta^{13} \mathrm{C}=-15.2 \%$

$570 \pm 45$

$\delta^{13} C=-11.4 \%$

$980 \pm 40$

$\delta^{13} \mathrm{C}=+1.4 \%$

$1070 \pm 80$

$\delta^{13} C=+0.7 \%$

$960 \pm 45$

$\delta^{13} \mathrm{C}=+1.0 \%$

$960 \pm 45$

$\delta^{13} C=+1.0 \%$

$980 \pm 40$

$\delta^{13} \mathrm{C}=+1.0 \%$

$950 \pm 45$

$\delta^{13} \mathrm{C}=+1.0 \%$

N.B.: see Higham (1993); Anderson, Smith and Higham (1996).

Warrington (144/177)

(Submitted by B. J. Allingham, Seacliff, R.D.1, Warrington) 
Wk-1737. W5

$1040 \pm 50$

Shell (Paphies subtriangulatum)

$\delta^{13} C=+1.2 \%$

Comment: (B.J.A.) Dates base of lowest cultural layer at Warrington site I44/177.

Wk-1738.

$870 \pm 50$

Shell (Austrovenus stutchburyi)

$\delta^{13} \mathrm{C}=+1.2 \%$

Comment: (B.J.A.) Sample dates period of moa decline in the Blueskin Bay area of the Otago coast. The sample should also date the upper Maori cultural layer of site I44/177.

Wk-1739.

Shell (Austrovenus stutchburyi)

$840 \pm 45$

$\delta^{13} \mathrm{C}=+1.2 \%$

Comment: (B.J.A.) Sample dates an early period of occupation at site I44/177.

Wk-2744. W9

$590 \pm 45$

Moa eggshell

$\delta^{13} C=-14.7 \%$

N.B.: Wk-2744 submitted in 1992 by T. Higham, Radiocarbon Dating Laboratory, University of Waikato.

\section{Papatowai (G47/50)}

(Submitted 25 June 1990, by I. W. G. Smith, Department of Anthropology, University of Otago)

\section{Wk-1761. THK/1}

Charcoal

$$
\delta^{13} C=\begin{array}{r}
650 \pm 45 \\
-25.9 \%
\end{array}
$$

N.B.: wood identified as twig from following species; manuka (Leptospermum scoparium), ribbonwood (Hoheria sp.), fivefinger (Pseudopanax arboreus), horopito (pepper tree) (Pseudowintera colorata), beech (Nothofagus sp.), Coprosma sp., Pittosporum sp., Archeria traversii.

Wk-1762. THK/9

$640 \pm 45$

Charcoal

$$
\delta^{13} \mathrm{C}=-25.4 \%
$$

N.B.: wood identified as manuka (Leptospermum scoparium), raukawa (Pseudopanax edgerleyi), mapou (Myrsine australis), ribbonwood (Hoheria sp.), Dracophyllum sp. See Anderson and Smith (1992).

\section{REFERENCES}

Allen, H., Phillips, C., Skipper, A., Te MoananuiWaikato, J., Reidy, C and Cook, B. (ms.) 1994 TaskForce Green/University of Auckland Archaeological Project, Waihou River (1993). Department of Anthropology, University of Auckland.

Anderson, A. J. 1989 Prodigious Birds: Moas and Moahunting in Prehistoric New Zealand. Cambridge, Cambridge University Press: 238 p.

1991 The chronology of colonization in New Zealand. Antiquity 65(249): 767-795.

1996 Was Rattus exulans in New Zealand 2000 years ago? AMS radiocarbon ages from Shag River Mouth. Archaeology in Oceania 31: 178-184.

Anderson, A. J. and McFadgen, B. G. 1990 Prehistoric two-way voyaging between New Zealand and East
Polynesia: Mayor Island obsidian on Raoul Island and possible Raoul Island obsidian in New Zealand. Archaeology in Oceania 25: 37-42.

Anderson, A. J. and McGovern-Wilson, R. 1990 The pattern of prehistoric Polynesian colonisation in New Zealand. Journal of the Royal Society of New Zealand 20(1): 41-63.

Anderson, A. J. and Smith, I. W. G. 1992 The Papatowai site: New evidence and interpretation. Journal of the Royal Society of New Zealand 101: 129-158.

Anderson, A. J., Smith, I. W. G. and Higham, T. F. G. 1996 Radiocarbon chronology. In Anderson, A. J., Smith, I. W. G. and Allingham, B. J., eds., Shag River Mouth: The Archaeology of an Early Southern Maori Village. Australian National University Research Pa- 
pers in Archaeology and Natural History 27. Canberra, ANH Publications, RSPAS: 60-69.

Beavan, N. R. and Sparks, R. J., in press, Factors influencing ${ }^{14} \mathrm{C}$ ages of the Pacific rat Rattus exulans. Proceedings of the 16th International Radiocarbon Conference. Radiocarbon.

Bedford, S. and Allen, H. 1993 When is a shell midden not just a shell midden? Archaeology in New Zealand 36(3): 120-134.

Best, S. (ms.) 1992 The Queen Street gaol: Auckland's first courthouse, common gaol and house of correction (site R11/1559). Department of Conservation, Auckland.

Bowers, L. and Jones, K. 1991 Tauwhare pa archaeological investigation and site restoration. Department of Conservation Technical Report Series 9. Department of Conservation, Rotorua.

Bulmer, S. 1994 Sources for the archaeology of the Maaori settlement of the Taamaki volcanic district. Science and Research Series 63. Department of Conservation, Wellington.

Bulmer, S. and Maingay, J. (ms.) An interim report on the investigation of pa site N7/70 at Butler Point, Mangonui Harbour. In preparation.

Caughley, G. 1988 The colonisation of New Zealand by the Polynesians. Journal of the Royal Society of New Zealand 18: 245-270.

Chester, P. (ms.) 1986 Forest clearance in the Bay of Islands. M.A. thesis, Department of Anthropology, University of Auckland.

Coplen, T. B. 1994 Reporting of stable hydrogen, carbon and oxygen isotopic abundances. Pure and Applied Chemistry 66: 273-276.

Currie, L. A. and Polach, H. A. 1980 Exploratory analysis of the international radiocarbon cross-calibration data: Consensus values and interlaboratory error. Preliminary note. In Stuiver, M. and Kra, R. S., eds., Proceedings of the 10th International ${ }^{14} \mathrm{C}$ Conference. $R a$ diocarbon 22(3): 933-935.

Davidson, J. 1981 The Polynesian Foundation. In Oliver, W. H and Williams, B. R., eds., The Oxford History of New Zealand. Wellington, Oxford University Press: 3-27.

1984 The Prehistory of New Zealand. Auckland, Longman Paul: $270 \mathrm{p}$.

Doelman, T. E. (ms.) 1995 Te Awa a Korako: The archaeology and ethnohistory of Te Kiri Kiri. M.A. thesis, University of Auckland.

Elliot, M. B., Striewski, B., Flenley, J. R. and Sutton, D. G. 1995 Palynological and sedimentological evidence for a radiocarbon chronology of environmental change and Polynesian deforestation from Lake Taumatawhana, Northland, New Zealand. Radiocarbon 37(3): 899-916.

Fredericksen, C. and Visser, E. 1989 Archaeological Excavations at Site R11/1519, Cryers Road, East Tamaki, Auckland, New Zealand. Science and Research
Series No. 21. Wellington, Science and Research Division, Department of Conservation.

1991 Calibrated radiocarbon dates from Cryers Road (R11/1519): A correction. Archaeology in New Zealand 34(3): 161-162.

Furey, L. 1991 Excavations at Whitipirorua, T12/16, Coromandel Peninsula. Records of the Auckland Institute and Museum 28: 33-68.

Gulliksen, S. and Scott, E. M. 1995 Report of the TIRI workshop, Saturday 13 August 1994. In Cook, G. T., Harkness, D. D., Miller, B. F. and Scott, E. M., eds., Proceedings of the 15 th International ${ }^{14} \mathrm{C}$ Conference. Radiocarbon 37(2): 820-821.

Higham, T. F. G. (ms) 1993 Radiocarbon dating the prehistory of New Zealand. D.Phil. thesis, University of Waikato, Hamilton.

1994 Radiocarbon dating New Zealand prehistory with moa eggshell: Some preliminary results. Quaternary Geochronology (Quaternary Science Reviews) 13: 163-169.

Higham, T. F. G and Hogg, A. G. 1995 Radiocarbon dating of prehistoric shell from New Zealand and calculation of the $\Delta \mathrm{R}$ value using fish otoliths. In Cook, G. T., Harkness, D. D., Miller, B. F. and Scott, E. M., eds., Proceedings of the 15 th International ${ }^{14} \mathrm{C}$ Conference. Radiocarbon 37(2): 409-416.

Higham, T. F. G and Johnson, L., in press, The date of prehistoric occupation at Raoul Island, the Kermadec group. Archaeology in Oceania.

Hogg, A. G. 1992 Assessment of 0.3-ml minivials for radiocarbon dating by liquid scintillation counting of benzene. In Long, A. and Kra, R. S., eds., Proceedings of the 14th International ${ }^{14} \mathrm{C}$ Conference. Radiocarbon 34(3): 389-393.

Hogg, A. G., Higham, T. F. G. and Dahm, J., in press, Radiocarbon dating of modern marine and estuarine shellfish. Proceedings of the 16 th International Radiocarbon Conference. Radiocarbon.

Hogg, A. G., Higham, T., Robertson, S., Beukens, R., Kankainen, T., McCormac, F. G., van der Plicht, J. and Stuiver, M. 1995 Radiocarbon age assessment of a new IAEA Quality Assurance material. In Cook, G. T., Harkness, D. D., Miller, B. F. and Scott, E. M., eds., Proceedings of the 15 th International ${ }^{14} \mathrm{C}$ Conference. Radiocarbon 37(2): 797-803.

Hogg, A. G., Lowe, D. J. and Hendy, C. 1987 Waikato Date List 1. Radiocarbon 29(2): 263-301.

Holdaway, R. N. 1996 Arrival of rats in New Zealand. Nature 384: 225-226.

Hooker, R. H. (ms.) 1986 The archaeology of the South Westland Maori. New Zealand Forest Service Report, Hokitika.

Jacomb, C. (ms.) 1995 Panau, periodisation and northeast South Island prehistory. M.A. thesis, Anthropology Department, University of Otago, Dunedin.

Johnson, L. 1991 A History and Archaeological Survey of Raoul Island, Northern Kermadec Islands. A report 
produced in fulfillment of Key Output 31 of the Department of Conservation, Auckland Conservancy 1990/91 Business plan. Auckland, Department of Conservation: $71 \mathrm{p}$.

1992 Archaeological Investigation of Site O04/116, Oparahi, Mangonui, Northland. Auckland Conservancy Historic Resource Series No. 3. Auckland, Department of Conservation.

1995 In the Midst of a Prodigious Ocean: Archaeological Investigations of Polynesian Settlement of the Kermadec Islands. Auckland Conservancy Historic Resources Series No. 11. Auckland, Department of Conservation: $100 \mathrm{p}$.

Jones, K. L. 1990 Settlement chronology on river terrace landforms: A New Zealand case study. Geoarchaeology 5(3): 255-273.

Kirch, P. V. 1986 Rethinking East Polynesian prehistory. Journal of the Polynesian Society 95(1): 9-40.

Kuzmin, Y. V. and Tankersley, K. B. 1996 The colonization of Eastern Siberia: An evaluation of the Palaeolithic age radiocarbon dates. Journal of Archaeological Science 23(4): 577-85.

Law, R. G. (ms.) 1984 Archaeological carbon dating using shell - the New Zealand experience. Paper presented at the New Zealand Archaeological Association Conference, Oamaru, 1984.

Lowe, D. J., McFadgen, B. G., Higham, T. F. G., Hogg, A. G., Froggatt, P. C. and Nairn, I. A., in press, Radiocarbon age of the Kaharoa tephra, a key marker for late Holocene stratigraphy and archaeology in New Zealand. Submitted to The Holocene.

McCormac, F. G., Hogg, A. G., Higham, T. F. G., LynchSteiglitz., J., Broecker, W., Baillie, M. G. L., Palmer, J., Xiong., G. L., Brown, D. and Hoper, S. T., in preparation, Interhemispheric difference in $\Delta^{14} \mathrm{C}$ : $\mathrm{An}$ anthropogenic $\mathrm{CO}_{2}$ effect.

McFadgen, B. G. 1980 Maori Plaggen soils in New Zealand, their origin and properties. Journal of the Royal Society of New Zealand 10(1): 3-18.

1982a Dating New Zealand archaeology by radiocarbon. New Zealand Journal of Science 25: 379-92.

1982b Report to NZHPT on Authority Application for site N56/18. NZHPT Report, Wellington.

, in press, The pre-European Maori Archaeology of the Wellington Conservancy: A prehistoric and palaeoenvironmental study. Wellington, Department of Conservation

McFadgen, B. G., Knox, F. B. and Cole, T. R. L. 1994 Radiocarbon calibration curve variations and their implications for the interpretation of New Zealand prehistory. Radiocarbon 36(2): 221-236.

Newnham, R. M., Lowe, D. J., McGlone, M. S., Wilmshurst, J. M. and Higham, T. F. G., in press, The Kaharoa Tephra as a critical datum for earliest human impact in northern New Zealand. Journal of Archaeological Science.
Pain, C. F. 1979 Radiocarbon ages from dune sands near Aotea and Kawhia Harbours, North Island, New Zealand. New Zealand Journal of Geology and Geophysics 22(2): 291-292.

Phillips, C. and Allen, H. 1996 Anatere pa, Athenree, Bay of Plenty. Archaeology in New Zealand 39(4): 264-277.

Polach, H. A. 1976 Correlation of ${ }^{14} \mathrm{C}$ activity of NBS Oxalic Acid with Arizona 1850 wood and ANU Sucrose standards. In Berger, R. and Suess, H. E., eds., Radiocarbon Dating. Proceedings of the Ninth International Conference, Los Angeles and La Jolla, 1976. Berkeley, University of California Press: 115-124.

Prickett, N. 1992 Archaeological excavations at Raupa: The 1988 Season. Records of the Auckland Institute and Museum 29: 25-101.

Rozanski, K., Stichler, W., Gonfiantini, R., Scott, E. M., Beukens, R. P., Kromer, B. and van der Plicht, J. 1992 The IAEA ${ }^{14} \mathrm{C}$ intercomparison exercise 1990. In Long, A. and Kra, R. S., eds., Proceedings of the 14th International ${ }^{14} \mathrm{C}$ Conference. Radiocarbon 34(3): 506-519.

Schmidt, M. D. (ms.) 1993 "Few have been tested by the spade...": $\mathrm{Pa}$ excavation and radiocarbon dating in New Zealand archaeology. M.A thesis, University of Auckland.

1996. The commencement of $\mathrm{Pa}$ construction in New Zealand Prehistory. Journal of the Polynesian Society 105: 441-460.

Slocombe, A. 1996 Excavation of a waterlogged site near Kaikohe. Archaeology in New Zealand 39(1): 48-53.

Smith, I. W. G. 1994 Organisation and operation of the New Zealand Archaeological Site Recording Scheme. Archaeology in New Zealand 37(4): 282-299.

Spriggs, M. 1989 The dating of the Island Southeast Asian Neolithic: An attempt at chronometric hygiene and linguistic correlation. Antiquity 63: 587-613.

1996 Chronology and colonisation in Island Southeast Asia and the Pacific: New data and an evaluation. In Davidson, J., Irwin, G., Leach, F., Pawley, A. and Brown, D., eds., Oceanic Culture History: Essays in honour of Roger Green. Dunedin North, New Zealand, New Zealand Journal of Archaeology: 33-50.

Spriggs, M. and Anderson, A. J. 1993 Late colonisation of East Polynesia. Antiquity 67: 200-217.

Stuiver, M. and Becker, B. 1993 High-precision decadal calibration of the radiocarbon time scale, AD 19506000 BC. In Stuiver, M., Long, A. and Kra, R. S., eds., Calibration 1993. Radiocarbon 35(1): 35-65.

Stuiver, M. and Braziunas, T. F. 1993 Modeling atmospheric ${ }^{14} \mathrm{C}$ influences and ${ }^{14} \mathrm{C}$ ages of marine samples to 10,000 BC. In Stuiver, M., Long, A. and Kra, R. S., eds., Calibration 1993. Radiocarbon 35(1): 137-191.

Stuiver, M. and Pearson, G. W. 1993 High-precision bidecadal calibration of the radiocarbon time scale, $A D$ 1950-500 BC and 2500-6000 BC. In Stuiver, M., 
Long, A. and Kra, R. S., eds., Calibration 1993. Radiocarbon 35(1): 1-25.

Stuiver, M. and Polach, H. A. 1977 Discussion: Reporting of ${ }^{14} \mathrm{C}$ data. Radiocarbon 19: 355-363.

Stuiver, M. and Reimer, P. J. 1993 Extended ${ }^{14} \mathrm{C}$ data base and revised CALIB $3.0{ }^{14} \mathrm{C}$ age calibration program. In Stuiver, M., Long, A. and Kra, R. S., eds., Calibration 1993. Radiocarbon 35(1): 215-231.

Sutton, D. G. 1987 A paradigmatic shift in Polynesian prehistory: Implications for New Zealand. New Zealand Journal of Archaeology 9: 135-157.

1994 Conclusion: Origins. In Sutton, D. G., ed., The Origins of the First New Zealanders. Auckland, Auckland University Press: 243-258.

Trotter, M. M. 1968 On the reliability of charcoal for radiocarbon dating New Zealand archaeological sites. New Zealand Archaeological Association Newsletter 11: 86-8. 